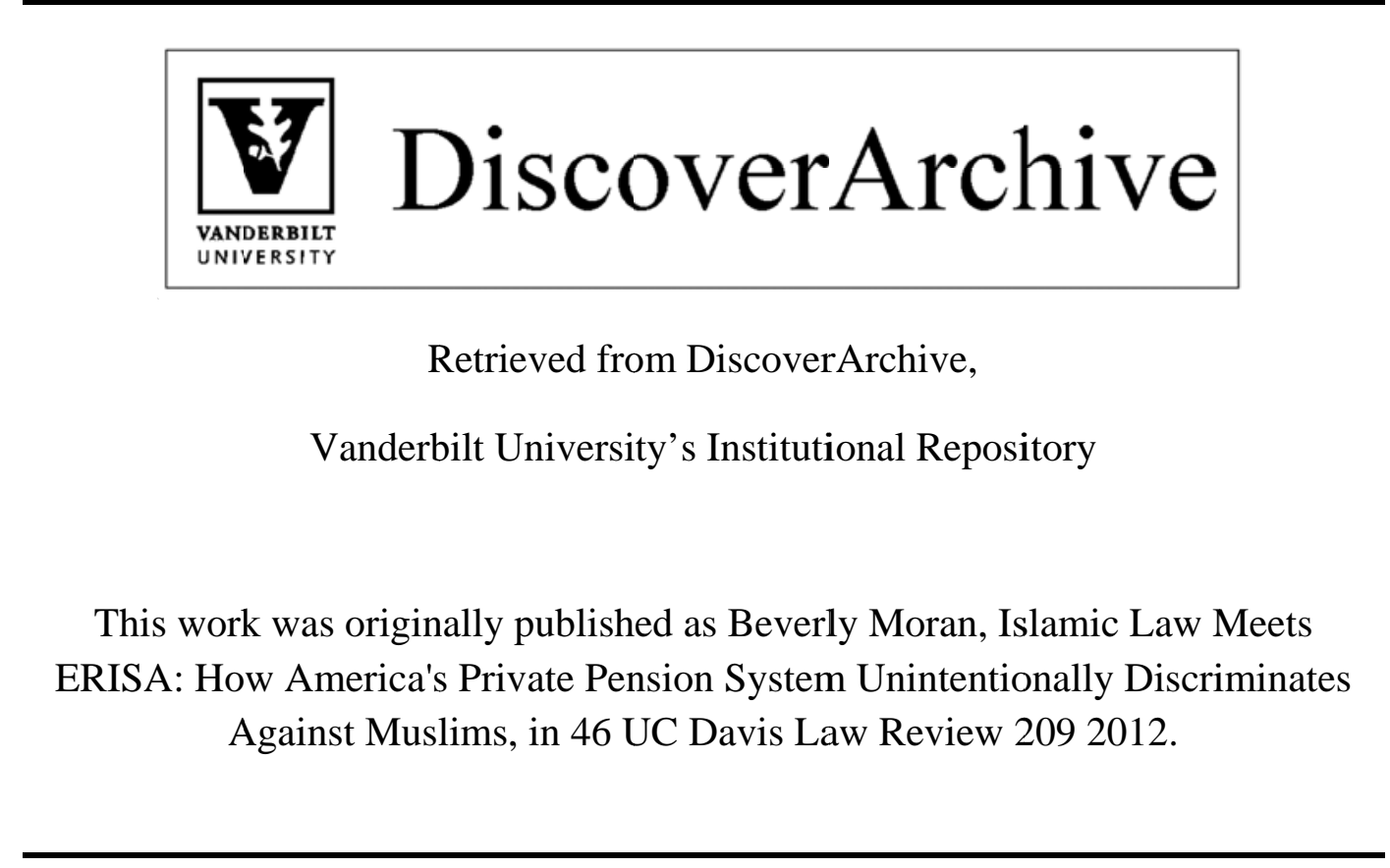




\section{HEINONLINE}

Citation: 46 U.C.D. L. Rev. 209 2012-2013

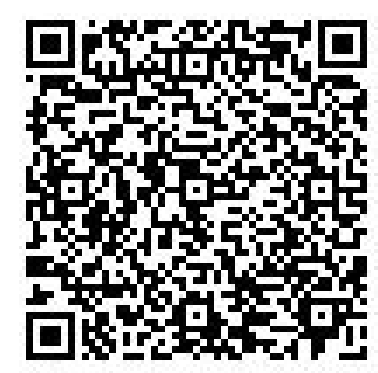

Content downloaded/printed from

HeinOnline (http://heinonline.org)

Wed Aug 20 09:31:59 2014

-- Your use of this HeinOnline PDF indicates your acceptance of HeinOnline's Terms and Conditions of the license agreement available at http://heinonline.org/HOL/License

-- The search text of this PDF is generated from uncorrected OCR text.

-- To obtain permission to use this article beyond the scope of your HeinOnline license, please use:

https://www.copyright.com/ccc/basicSearch.do?

\&operation $=$ go\&search Type $=0$

\&lastSearch $=$ simple\&all=on\&titleOrStdNo=0197-4564 


\title{
Islamic Law Meets ERISA: How America's Private Pension System Unintentionally Discriminates Against Muslims and What To Do About It
}

\author{
Beverly I. Moran*
}

This article asks whether Muslims whose religious beliefs prevent investment in their employers' private pension plans have a right to religious accommodation. This is a real issue for a growing part of the population whose spiritual lives are governed by rules that prohibit the giving or taking of interest. As one might expect, the investments available through most American pension plans involve some aspect of interest making those investments unsuitable retirement vehicles for devout Muslims. Consequently, in order to secure their retirement income, Muslims are faced with either violating their religious beliefs, losing years of investment opportunity as they wait for the American investment market to catch up to their religious needs, relying on their employer's goodwill, or religious accommodation through court or statute. Religious accommodation in the workplace is governed by the Equal Employment Opportunity Act (Title VII). The statute is directive and punitive. There are potential money damages if an employer does not comply with Title VII's religious accommodation requirement but no benefit (monetary or otherwise) in exchange for compliance. The two Supreme Court decisions

* Copyright (C) 2012 Beverly I. Moran. Professor of Law and Professor of Sociology, Vanderbilt University Law School, A.B. Vassar College, J.D. University of Pennsylvania, LL.M New York University. Thanks to the Seton Hall University Faculty Scholarship Workshop, the Southeastern American Law Schools Scholarship Workshop, and the Vanderbilt Law School Brown Bag Series. Thanks to Julia Luster and the staff of the UC Davis Law Review. Thanks also to Lisa Bressman, Robert Covington, Dirk Hartog, Beth Hickman, Janet Hirt, Stephen Jordan, Suzanna Sherry, Leon Trakman, Joan Vogel, and Stephanie Wildman for their comments and assistance. 
that look at religious accommodation under Title VII concern private employers asked to rearrange employee work schedules to accommodate Sabbatarians. Where the employer faced a potential penalty for failure to provide religious accommodation but no benefit for compliance with the statute's requirements, the Court treated the Title VII accommodation obligation as an Establishment of religion and as a burden on the nonbelievers' Free Exercise rights. Accordingly, the Court diminished Congress's religious accommodation rule under Title VII to the point that no motivated employer need ever accommodate an employee's religious practice. Not all religious accommodations occur in the same context. As opposed to religious accommodation under Title VII, the Court generally gives Congress great deference when the legislature bestows tax benefits in exchange for taxpayers eschewing even constitutionally protected activities. Private pension plans are founded on tremendous tax benefits bestowed on retirement accounts by the Employee Retirement Income Security Act (ERISA). These benefits invoke the deference to Congress exhibited in the Court's tax decisions rather than the hostility to forced religious accommodation reflected in its Title VII decisions.

\section{TABLE OF CONTENTS}

INTRODUCTION

I. ERISA AND TITLE VII: HOW PENSION PLANS CONFLICT WITH RELIGIOUS ACCOMMODATION

A. Employment Retirement Income Security Act (ERISA) ....... 219

B. ERISA and the Equal Employment Opportunity Act (Title VII)

1. Manhart and Norris - Sex Discrimination and Pensions.

2. Gilbert v. General Electric - Sex Discrimination and Welfare Plans

C. The Equal Employment Opportunity Act (Title VII) and Religious Accommodation

1. EEOC Creates Religious Accommodation ................. 228

2. Supreme Court Rejects Religious Accommodation ... 228

3. Congress Requires Religious Accommodation .......... 229

4. The Supreme Court Refuses to Enforce Religious Accommodation

5. Contrasting Supreme Court Pronouncements and EEOC Rules

6. How Should Employers Handle Requests for Religious Accommodation? 
II. ISLAMIC LAW AND THE CONNECTION BETWEEN RELIGION AND PENSION INVESTMENT.................................................. 235

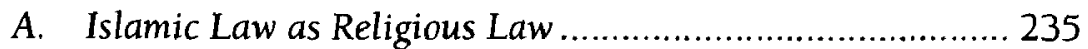

B. Islamic Prohibitions Against Usury .................................. 238

C. Sharia-Compliant Funds................................................ 238

III. THE SUPREME COURT's TAX JURISPRUDENCE AND HOW IT DIFFERS FROM ITS TITLE VII ANALYSIS ................................... 240

A. Tax Subsidy as Tax Expenditure ...................................... 241

B. Exchange of Constitutional Right for Government

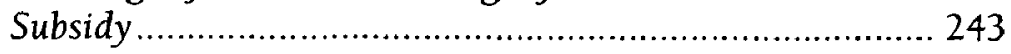

1. South Dakota v. Dole ................................................ 243

2. Bob Jones University v. United States ......................... 243

3. Regan v. Taxation with Representation ...................... 244

C. Statutory Interpretation .................................................. 245

IV. BORROWING FROM TAX JURISPRUDENCE: WHAT WOULD RELIGIOUS ACCOMMODATION LOOK LIKE IN THE PENSION

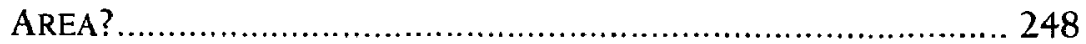

A. Sincerely Held Religious Belief......................................... 249

B. Religious Restrictions on Financial Transactions ............... 251

C. Not Accommodated Within the Ordinary Course of Employment .................................................................. 252

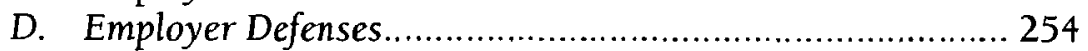

V. ACADEMICS AND RELIGIOUS ACCOMMODATION...................... 255

A. Equal Liberty - An Exemption Based on Equal Regard..... 256

B. Substantive Neutrality - Discretionary Accommodation and Occasional Mandatory Accommodation ..................... 260

\section{INTRODUCTION}

The United States is changing. ${ }^{1}$ If we were ever a Protestant country with English values, we now resemble the rest of the developed world which is to say that our population reflects more than a single religion, race, or ethnic group. ${ }^{2}$ Our neighbors are Catholics and Jews, Muslims

1 See U.S. Census Bureau, Statistical Abstract of the United States, 61, tbl.75 (2012), available at http://www.census.gov/compendia/statab/2012/tables/12s0075.pdf (showing that Americans are slowly becoming less Christian). The U.S. Bureau of the Census is constitutionally precluded from inquiry into religion and since 2003 has incorporated a tabulation of religious self-identification into the STATISTICAL ABSTRACT of THE United States. See Barry A. Kosmin \& Ariela Keysar, American Religious IDENTIFICATION SURVEY (ARIS) 2008 5, tbl.3 (2009), available at http://commons.trincoll.edu/aris/files/2011/08/ARIS_Report_2008.pdf.

2 See KOSMIN \& KeYSAR, supra note 1, at 14-22 (depicting tables of social 
and Sikhs, Buddhists and Hindus, and holders of all other manner of beliefs and devotions. ${ }^{3}$

This article explains how our demographic transformation is heading toward conflict with our legislative and judicial policies resulting in unexpected and unfortunate consequences for our government subsidized private retirement system. The combination of Congress's decision to subsidize private pensions through the Internal Revenue Code and the Supreme Court's restrictive understanding of the obligation to accommodate religion under the Equal Employment Opportunity Act (Title VII) leaves a growing group of private sector employees without access to the protections of the Employee Retirement Income Security Act (ERISA). ${ }^{4}$ Consider the following scenario:

The Human Resources Director of a Fortune 500 company explains that his Company prides itself on its global positioning, including its leadership in creating a diverse national and international workforce. In order to keep its varied workforce happy and productive, the Company voluntarily accommodates various types of religious headgear, jewelry, and facial hair. In addition, the Company's large number of employees allows for a fair amount of scheduling flexibility with non-Christian employees working during Christian holidays while Christian employees cover non-Christian holidays.

variables, such as racial composition, education and geographical distribution, which suggests that Americans are becoming more diverse in terms of race and ethnic origin); see also Brian J. Grim ET al., THE Future of the Global Muslim Population, Pew-Templeton Global Religious Futures Project 21 (2011), available at http://pewforum.org/uploadedFiles/Topics/Religious_Affiliation/Muslim/FutureGlobal MuslimPopulation-WebPDF-Feb10.pdf (determining that $64.5 \%$ of the Muslims in the U.S. today are first-generation immigrants and that by $2030,44.9 \%$ of the Muslims in the U.S. will be native-born); The Global Muslim Population, PEWFORUM.ORG, http://features.pewforum.org/muslim-population-graphic/ (last visited Sept. 16, 2012) (allowing a user to select a region and specific time to show the actual or projected Muslim population).

${ }^{3}$ See Kosmin \& Keysar, supra note 1 , at 18-22, tbl.12 (showing how the American religious map has been redrawn at the state, Census Division, and regional levels - for example, Catholic numbers and percentages rose in many states in the South and West, while at the same time they declined in the Northeast Region).

${ }^{4}$ See generally Employee Retirement Income Security Act of 1974, 29 U.S.C. $\S \S$ 1001-1461 (2012) (discussing at length Congress's decision in ERISA to give employers control over investment choices combined with the Supreme Court's interpretation of Title VII to give employers control over religious accommodation, which unintentionally creates a private retirement system without options for people who are religiously prohibited from participating in common financial transactions, usually the taking or giving of interest on loans). 
Imagine the Human Resources Director's surprise when his Company's Muslim employees requested a Sharia-compliant investment option within the employer-sponsored pension plan. ${ }^{5}$ As a Roman Catholic, the Human Resources Director was vaguely aware that his Church instructs members to invest with an eye toward the sacredness of human life and the alleviation of poverty as well as the Church's prohibition against usury. But the Human Resources Director is unaware of the Islamic law of finance. ${ }^{6}$ It now occurs to the Human Resources Director and his Company's Board of Directors that other employees might have religious and ethical attitudes towards their pension fund investments, as well. Must the Company do anything in the face of an employee request for religious accommodation in the Company's private pension plan investment options?

Under the Supreme Court's workplace accommodation jurisprudence, the Company need not accommodate its Muslim employees' requests for Sharia-compliant investment options. ${ }^{7}$ The

5 See Mohd Daud Bakar, The Shari'a supervisory board and issues of Shari'a rulings and their harmonization in Islamic banking and finance, in ISLAMIC FINANCE: INNOVATION AND GROWTH 74-80 (Simon Archer \& Rifaat Ahmed Abdel Karim eds., Euromoney Books 2002) (stating that these boards, comprised of experts in Islamic law, consult with financial institutions on their investments in order to ensure compliance with Islamic law); Mohamed A. Elgari, Islamic Equity Investment, in IsLAMIC FINANCE: INNOVATION AND GROWTH 151 (Simon Archer \& Rifaat Ahmed Abdel Karim eds., Euromoney Books 2002) (stating that "[o]ne of the most distinct phenomena in the Muslim world today is the increased desire of Muslims to comply in all aspects of their life with the requirements of Shari'a law. This includes economic and financial aspects ....").

6 See generally Mahmoud A. El-Gamal, Islamic FinanCe: LaW, ECONOMICS, AND PRACTICE XI (2006) (providing "a qualitative overview of the practice of Islamic finance and the historical roots defining its modes of operation"); Swapna Gopalan, Overview in Islamic Capital Markets: OpPoRtunities and Challenges I-VI (Swapna Gopalan ed., 2009) (indicating that "by 2006, there were more than 300 Islamic financial institutions in over 75 countries worldwide with approximately $\$ 400$ billion capital market assets"); Swapna Gopalan, Capital Markets under Islamic Principles, in ISLAMIC CAPITAL Markets: OpPORTUNITIES AND Challenges 1-13 (Swapna Gopalan ed., 2009).

7 See discussion infra Part I.C.4. The Supreme Court refuses to enforce religious accommodation. The law of religious discrimination in employment has been shaped by Trans World Airlines, Inc. v. Hardison, 432 U.S. 83 (1977) and Ansonia Bd. of Educ. v. Philbrook, 470 U.S. 60 (1986). Both cases focus the lens of accommodation on the employer, determining that no employee receives accommodation if doing so would burden the employer. See also Robert J. Friedman, Religious Discrimination in the Workplace: The Persistent Polarized Struggles, 11 TRANSACTions: TenN. J. Bus. L. 143, 157 (2010) (stating that employers can escape accommodation by claiming financial loss or production loss). 
federal agency in charge of monitoring religious accommodation in the workplace has rules obligating employers to reasonably accommodate their employees' religious practices unless every reasonable alternative creates an undue business hardship. ${ }^{8}$ Nevertheless, in light of the Supreme Court's workplace accommodation jurisprudence, these Equal Employment Opportunity Commission (EEOC) rules are essentially powerless against any employer willing to refuse accommodation. The Supreme Court's decisions in Trans World Airlines, Inc. v. Hardison and Ansonia Board of Education v. Philbrook allow any motivated employer to avoid religious accommodation under Title VII. ${ }^{9}$

This Article argues that the Supreme Court's Sabbatarian accommodation in the workplace jurisprudence is ill suited to a request for religious accommodation for pension investments. In Hardison and Ansonia, for example, the Court framed the requests for Sabbatarian accommodation as a government imposition on private employers in order to privilege religion. Further, this government interference with the private workplace is without any corresponding benefit from the government to the employer. If the employer fails to accommodate, the employer faces punishment. But if the employer

829 C.F.R. \& 1605.2 (2011) (declaring that an employer has "an obligation to reasonably accommodate ... religious practices" and "[a] refusal to accommodate is justified only when an employer ... can demonstrate that an undue hardship would in fact result from each available alternative method of accommodation").

In 2008, the EEOC issued Directive No. 915.003, the sixth section of its New Compliance Manual, wherein Section 12 indicates that partial accommodation is not reasonable where full accommodation poses no hardship:

\section{EXAMPLE 32}

Employer Violates Title VII if it Offers Only Partial Accommodation Where Full Accommodation Would Not Pose an Undue Hardship

Rachel, who worked as a ticket agent at a sports arena, asked not to be scheduled for any Friday night or Saturday shifts, to permit her to observe the Jewish Sabbath from sunset on Friday through sunset on Saturday. The arena wanted to give Rachel only every other Saturday off. The arena's proposed accommodation is not reasonable because it does not fully eliminate the religious conflict. The arena may deny the accommodation request only if giving Rachel every Saturday off poses an undue hardship for the arena.

Equal Employment Opportunity Comm'n, EeOC Compliance Manual Directive No. 915.00358 (July 2008), available at http://www.eeoc. gov/policy/docs/religion.pdf.

9 Hardison, 432 U.S. at 84 (stating that to require an employer "to bear more than a de minimis cost ... is an undue hardship"); Ansonia, 479 U.S. at 68-69 (determining that "any reasonable accommodation by the employer is sufficient"). 
does accommodate, the employer receives nothing of value from government in exchange for its cooperation.

In the Sabbatarian accommodation cases, the employer receives nothing of value from the government if it provides accommodation. The accommodation requirement is a sort of unfunded mandate where the Congress imposes a cost without providing the means to pay. In its Sabbatarian accommodation decisions, the Supreme Court asks very little from the employer. In contrast, when Congress is actually supplying funds for its mandates, the Supreme Court allows Congress to impose its will on private citizens even if those citizens are only engaged in private transactions.

For example, in South Dakota v. Dole, the State was forced to relinquish its police powers in exchange for government subsidy. ${ }^{10}$ In other words, the Court allowed Congress to premise a government subsidy on the State relinquishing its rights. Using similar reasoning to South Dakota v. Dole, the Supreme Court gave government the right to force taxpayers to give up constitutional rights in exchange for tax benefits in Bob Jones University v. United States, where the Supreme Court let the Treasury premise tax benefits on the taxpayer refraining from its right to the Free Exercise of Religion, and in Regan v. Taxation with Representation where Congress denied the taxpayer the right to Petition Government. ${ }^{11}$

Dole, Bob Jones University, and Taxation with Representation each represent much greater impositions on constitutional freedoms than the Sabbatarian accommodation at stake in Hardison and Ansonia. ${ }^{12}$ Each of these decisions stands for Congress's right to demand private actions from private people in exchange for government subsidy. Private pension plans are subsidized through tax benefits to both

10 South Dakota v. Dole, 483 U.S. 203, 209-12 (1987) (determining that Congress had not exceeded its spending powers or violated the Twenty-First Amendment, by passing legislation conditioning the award of federal highway funds on the states' adoption of a uniform minimum drinking age. Congress did not violate the Constitution by indirectly encouraging uniformity in the states' legal drinking age because legislation was in pursuit of "the general welfare" and the means were reasonable.).

11 See Bob Jones Univ. v. United States, 461 U.S. 574, 602-04 (1983) (upholding denial of tax-exempt status to private schools that racially discriminate because of sincerely held beliefs and stating that the governmental interest in eradicating racial discrimination outweighs whatever burden tax benefits place on petitioner's exercise of his or her religious beliefs); Regan v. Taxation with Representation of Wash., 461 U.S. 540, 542-51 (1983) (holding no infringement of any First Amendment rights nor violation of the equal protection component of the Fifth Amendment in the government's choosing not to subsidize the plaintiff's lobbying with public funds).

12 See cases cited supra note 11. 
employers and employees. ${ }^{13}$ Congress can impose greater obligations on employers that receive ERISA's tax benefits than it can impose on employers who are setting up work schedules.

The difference between the employer that the Supreme Court protects against the imposition of religious accommodation in the workplace and the exempt charitable organization that the Supreme Court does not protect in Bob Jones and Taxation with Representation is government subsidy. If what Congress asks in exchange for a tax benefit is that taxpayer's eschew their constitutional rights, then the Supreme Court will enforce the statute. ${ }^{14}$ As for the taxpayer, it can decline the benefit if the constitutional right is too dear to renounce. ${ }^{15}$

Virtually no private activity receives more federal subsidy than the ERISA private pension system. ${ }^{16}$ The tax benefits generated through private pensions touch almost half of all private sector employees, helping them shelter trillions of dollars from tax. ${ }^{17}$ As such, both employers and employees receive ERISA tax benefits. Thus, when Congress directs employers to accommodate religious practice in the workplace in exchange for the right to qualify an ERISA pension plan,

13 See discussion infra, Part III.A.

14 See discussion infra, Part 111.

15 See discussion infra, Part III. Although a strong value in tax jurisprudence, the Court makes similar declarations in such non-tax areas as waivers of sovereign immunity. See, e.g., Dole, 483 U.S. at 203-08 (finding the federal government can restrict monies for state highways based on requiring states to adopt specific restrictions); see also Rebecca E. Zietlow, Federalism's Paradox: The Spending Power and Waiver of Sovereign Immunity, 37 WAKE FOREST L. REV. 141, 216 (2002) (concluding that the spending power of Congress "helps to retain the balance between federal and state power without undermining either"). There are also representative lower court opinions that approve states' consular waiver of their sovereign immunity in exchange for federal funds. See, e.g., Pace v. Bogalusa City Sch. Bd., 403 F.3d 272, 303 (5th Cir. 2005) (Jones, J., dissenting in part); A.W. v. Jersey City Pub. Sch., 341 F.3d 234, 255 (3d Cir. 2003); Jim C. v. United States, 235 F.3d 1079, 1085 (8th Cir. 2000).

16 According to the tax expenditure budget, pension contributions rank as the second-most costly tax benefit at an annual cost of $\$ 117.7$ billion. Gillian Reynolds \& C. Eugene Steuerle, Tax Expenditures: What Are the Largest Tax Expenditures?, in THE TAX POLICY BRIEFING BOOK: A CITIZENS GUIDE FOR THE 2008 ElECTION \& BEYOND 1-8-6 to 1-8-8 (2008), available at http://www.taxpolicycenter.org/briefing-book/background/ expenditures/largest.cfm.

${ }_{17}$ According to the U.S. Bureau of Labor, in March 2010, almost half of all private sector workers participated in a voluntary defined contribution plan. U.S. Bureau of Labor Statistics, Six Ways to Save for Retirement, 3 PROGRAM PERSPECTIVES 2 (2011), available at http://www.bls.gov/opub/perspectives/program_perspectives_vol3_issue3.pdf; see PETER J. WIEDENBECK, ERISA PRINCIPLES OF EMPLOYEe BENefit LAW 3 (Oxford University Press 2010) (stating that ERISA governed pension plans held more than $\$ 6$ trillion in assets at the close of 2007). 
that Congressional mandate deserves enforcement under prior Supreme Court precedent.

As opposed to the Sabbatarian accommodation requests the Court rejects under Title VII, in the context of private pension plans, Congress supports the employer obligation to accommodate religion with a substantial tax subsidy that the Supreme Court will likely recognize and uphold. While Hardison and Ansonia make workplace accommodation of religious headgear, jewelry, and facial hair essentially voluntary, Dole, Bob Jones University, and Taxation with Representation demonstrate that failure to provide religious accommodation in a private pension plan might threaten that plan's qualification under ERISA - making religious accommodation an enforceable obligation rather than a voluntary exercise. This Article posits that Congress through Title VII, the EEOC through its rules, and the Supreme Court through its decisions in Bob Jones University and Taxation with Representation, all support Congress's right to impose religious accommodation on employers as a requirement for plan qualification under ERISA.

Part I of this Article concerns ERISA and Title VII, showing how pension plans conflict with religious accommodation. A brief introduction is made to ERISA, which regulates the private pension system and provides the tremendous tax benefits to employers and employees that keep the private pension system robust. The only reason to create a qualified plan is to reap the ERISA tax benefits. ${ }^{18}$

Part I.B explains the connection between ERISA and the Equal Employment Opportunity Act (Title VII), so that a participant in an employer-provided pension plan can look to Title VII for protection against discrimination ERISA does not explicitly address. The Supreme Court's pronouncements on sex based pension benefits discrimination provide the connection between Title VII and ERISA.

Part I.C shows how classic Title VII jurisprudence allows any motivated employer to avoid all types of workplace religious accommodation despite a strong statutory mandate and an even more demanding set of administrative rules. Employers who are willing to take on the EEOC if challenged can rely on key Supreme Court decisions in order to avoid any religious accommodation whatsoever. Also noted is the Court's rejection of the employer's obligation to

18 See David A. Pratt \& Sharon ReEce, ERISA and Employee Benefit Law: The Essentials 15-30 (ABA Books 2010) (noting that 26 U.S.C. \& 404(a)(1)-(3) spells out the tax benefit to an employer that creates a qualified retirement plan, allowing the employer a current deduction for the amounts actually contributed to the plan). 
accommodate when Congress provides punishment for failure to comply but no benefit for compliance.

Part II introduces the Islamic law of finance and its prohibitions against the giving or taking of interest. Because of this law and other religious restrictions, devout Muslims are unable to take advantage of most employer-sanctioned pension investment options.

Part III looks at the employer benefit and asks: does Congress's power to demand employer compliance increase when the mandatory religious accommodation is wedded to a tax subsidy? By contrasting the Supreme Court's tax jurisprudence with its Title VII decisions, this Article shows that under Title VII, the Court focuses on protecting the employer from congressional mandates. But where Congress provides a substantial government subsidy in exchange for mandated behavior in other contexts, the Court allows the legislature to force taxpayers to perform the behavior Congress requests even if the requirement includes renouncing constitutional rights. Thus, even the most risktaking employer should consider that the Court has never faced a religious accommodation request made against the background of a substantial tax benefit. Accordingly, Part III argues that while other types of religious accommodation are voluntary, pension investments are made mandatory by the great government subsidy they receive through the Internal Revenue Code.

To better understand what religious accommodation would look like in the private pension arena, Part IV presents the standard Title VII religious accommodation analysis. As the right to religious accommodation is based on the interaction of Title VII and ERISA, Part IV introduces three issues under Title VII: sincerely held religious belief, non-accommodation within the ordinary course of employment, and employer defenses.

Part V shows that both equal liberty scholars and substantive neutrality scholars - usually on the opposite side of the religious accommodation issue - would both agree that religious accommodation for pension plan investments in the form of Shariaapproved funds is both constitutional and required. Equal liberty adherents would allow this religious accommodation under their equal regard standard while substantive neutrality proponents would find that an expanded choice of pension investments open to all plan participants maintains neutrality between the believer and the nonbeliever.

In sum, this Article concludes that as opposed to other types of religious accommodation, an employee's request for religious accommodation in pension fund options creates an employer obligation which, if left unmet, can threaten qualification of an ERISA- 
sponsored private pension plan. Further, two of the most active academic movements surrounding religious accommodation - one generally in favor of accommodation and the other generally opposed to accommodation - both support religious accommodation in pension investments, albeit for very different reasons.

\section{ERISA AND TITLE VII: HOW PENSION PLANS CONFLICT WITH RELIGIOUS ACCOMMODATION}

The problem this Article confronts is whether devout employees have enforceable religious accommodation rights in their employerprovided private pension plans. This question involves two very different statutes developed at different times and for different reasons. On the one hand, the employee looks to Title VII to find a right to religious accommodation in employment. Title VII articulates the right to religious accommodation in the workplace but is not strong enough to support the accommodation standing alone. Nevertheless, the question arises in the context of private pension plans which invites inspection of ERISA. ERISA confers rights that, when combined with Title VII, argue for religious accommodation in private pension plans.

\section{A. Employment Retirement Income Security Act (ERISA)}

The federal government regulates both mandatory and voluntary retirement programs. The two largest mandatory retirement programs are Social Security and Medicare. ${ }^{19}$ Voluntary pension plans are generally governed by ERISA. ${ }^{20}$ ERISA's rules appear in both the Labor Law Code and the Internal Revenue Code. ${ }^{21}$

ERISA is completely voluntary. Employers are not required to set up ERISA-qualified retirement plans and employees are not required to participate in ERISA-qualified pensions. ${ }^{22}$ Yet tens of thousands of

19 See generally Social Security Act of 1935, Pub. L. No. 74-271, 49 Stat. 620 (1935) (amended 1954 and 1956). In 1965, Medicare and Medicaid were formally enacted amendments to the Social Security Act and went into effect in 1966. Social Security Amendments of 1965, Pub. L. No. 89-97, 79 Stat. 286 (1965) (amending Social Security Act to include Title XVIII for Medicare and Title XIX for Medicaid).

2029 U.S.C. $\$ \$ 1001-1461$ (2012).

21 See id.; see also 26 U.S.C. $\$ \S 401-20$ (2012) (discussing the Internal Revenue Code's deferred Compensation plans such as pension, profit-sharing, and stock bonus)

2229 U.S.C. §§ 1001-1461; see also PRATT \& REECE, supra note 18, at 5-7 (indicating that "about 96 percent of American workers are covered by Social Security and over 90 percent of public sector employees are covered by a retirement plan, but only about 50 percent of private sector employees are covered by any other retirement 
employers maintain ERISA-governed retirement plans that serve millions of private sector workers and contain trillions of dollars in assets. ${ }^{23}$

ERISA's popularity rests on its protective regulations and generous tax benefits. The labor side of ERISA protects workers' expectations in their retirement rights. ${ }^{24}$ The tax side of ERISA gives employers immediate tax deductions and employees decades of tax deferral. ${ }^{25}$ ERISA gives employers control over pension plan sponsorship and design. ${ }^{26}$ Although employers are free to design any plan or no plan, ERISA's tax benefits only apply to "qualified plans." ${ }^{27}$ Qualified plans meet five statutory requirements:

plan," a plan that must comply with the applicable requirements of the Internal Revenue Code and ERISA).

${ }^{23}$ See U.S. Bureau of Labor Statistics, supra note 17, at 1 ("In March 2010, 41 percent of private sector works participated in employer-sponsored defined contribution plans.").

${ }^{24}$ Letter from Richard Nixon, President of the United States, to Congress of the United States (Apr. 11, 1983), available at 1973 WL 172968 (A.\&P.L.H.). See the remarks of Chairman of the House Education and Labor Committee, Carl Perkins:

In one sense, the purpose of this conference report is relatively simple. It is designed to reduce sharply the number of people who pay money into private pension plans year after year expecting eventually to receive retirement income only to have their hopes dashed and end up getting nothing.

It is the aim of this conference report to make pension plans more equitable and more sound. Workers will have to be permitted to participate in a covered pension plan within a reasonable time and at a reasonable age. Participating workers will have to achieve a vested interest after limited periods of service with an employer. Minimum funding standards will go a long way toward insuring the solvency of pension plans, toward insuring that when a worker retires there will be adequate dollars available to pay his pension. The adequacy of a pension plan's assets will be insured against the risk of termination by insuring the unfunded portion of the benefits.

H.R. REP. No. 93-1280, at 4657 (1974) (Conf. Rep.).

${ }^{25}$ See I.R.C. § 404 (2012) (employer gets an immediate deduction); I.R.C. § 501(a) (2012) (trust that holds employees' funds gets tax free appreciation for the entire time that the amounts are invested); I.R.C. $\$$ 402(c) (2012) (after a long deferral, the employee pays an ordinary income tax on withdrawals).

26 Treas. Reg. \& 1.401-1(a)(2) (2012) (requiring that a qualified plan be established and maintained by the employer); see also WIEDENBECK, supra note 17 , at 18-19.

27 I.R.C. $\$ 401$ provides the following provisions regarding qualified pension, profit-sharing, and stock bonus plans:

(a) Requirements for qualification 
1) all plan monies are dedicated to employee benefit, ${ }^{28}$

2) there are no harsh vesting requirements, ${ }^{29}$

3) highly compensated employees are not favored, ${ }^{30}$

4) employees are protected from pension-motivated termination or harassment, ${ }^{31}$ and

A trust created ... for the exclusive benefit of his employees . . [is] . . qualified ... under this section-

(1) if contributions are made to the trust by such employer, or employees, or both, ... for the purpose of distributing to such employees . . . the corpus and income of the fund accumulated by the trust...

(2) if under the trust instrument it is impossible, . . . for any part of the corpus or income to be ... used for, or diverted to, purposes other than for the exclusive benefit of his employees...

(3) if the plan of which such trust is a part satisfies the requirements of section 410 (relating to minimum participation standards); and

(4) if the contributions or benefits provided under the plan do not discriminate in favor of highly compensated employees (within the meaning of section 414 (q)). For purposes of this paragraph, there shall be excluded from consideration employees described in section $410(b)(3)(A)$ and (C).

28 I.R.C. \& 401(a)(1)-(2).

29 I.R.C. \$ 410 provides the following minimum participation standards:

(a) Participation

(1) Minimum age and service conditions

(A) General rule

A trust shall not ... [require], ... that an employee complete a period of service extending beyond the later of the following dates-

(i) the date on which the employee attains the age of 21 ; or

(ii) the date on which he completes 1 year of service

30 See I.R.C. $\$ 410(1)$ (B) (requiring that the plan be nondiscriminatory).

31 See 29 U.S.C. \$ 1140 (2012). The following discussion is included in ERISA regarding interference with protected rights:

It shall be unlawful for any person to discharge, fine, suspend, expel, discipline, or discriminate against a participant or beneficiary for exercising any right to which he is entitled under the provisions of an employee benefit plan, this subchapter, section 1201 of this title, or the Welfare and Pension Plans Disclosure Act [29 U.S.C. 301 et seq.], or for the purpose of interfering with the attainment of any right to which such participant may become entitled under the plan, this subchapter, or the Welfare and Pension Plans Disclosure Act. It shall be unlawful for any person to discharge, fine, 


\section{5) There is no penalty for working past retirement age..$^{32}$}

These five protections are incorporated into the documents that create each qualified plan. ${ }^{33}$

In addition to requirements for qualified plans, ERISA imposes fiduciary duties on plan managers. ${ }^{34}$ ERISA fiduciaries must exercise both "prudence and diligence" in their investment choices as well as guard against excessive fees. ${ }^{35}$ Prudence under ERISA is measured by

suspend, expel, or discriminate against any person because he has given information or has testified or is about to testify in any inquiry or proceeding relating to this chapter or the Welfare and Pension Plans Disclosure Act. In the case of a multiemployer plan, it shall be unlawful for the plan sponsor or any other person to discriminate against any contributing employer for exercising rights under this chapter or for giving information or testifying in any inquiry or proceeding relating to this chapter before Congress. The provisions of section 1132 of this title shall be applicable in the enforcement of this section.

32 I.R.C. \& 411(b)(1)(H)(i) discusses continued accrual beyond normal retirement age:

Notwithstanding the preceding subparagraphs, a defined benefit plan shall be treated as not satisfying the requirements of this paragraph if, under the plan, an employee's benefit accrual is ceased, or the rate of an employee's benefit accrual is reduced, because of the attainment of any age.

33 Treas. Reg. \$ 1.401-1(a)(2) requires that a qualified plan be in writing, established and maintained by the employer, and communicated to employees. Having each private retirement system reduced to a written plan is meant to protect workers' rights through the transparency of a single open document that every plan participant can access. See WIEDENBECK, supra note 17, at 28-32; see also Peter J. Wiedenbeck, Implementing ERISA: of Policies and "Plans", 72 WASH. U. L.Q. 559, 584 (1994).

34 See ERISA $\$ 404(a), 29$ U.S.C. \$ 1104 (a). ERISA imposes the duty of loyalty, duty of prudence, duty to diversify investments, duty of transparency, and the duty to follow plan documents to the extent that the documents comport with ERISA on all fiduciaries. These fiduciaries are usually selected by the employer. Qualified plan fiduciaries usually implement the plan documents and select the plan's investment choices. Employers are fiduciaries when they administer plans but not when they create, amend, or terminate plans. See Curtiss Wright Corp. v. Schoonejongen, 514 U.S. 73, 78 (1995) (finding an employer is not a fiduciary when amending or terminating a plan); Noorily v. Thomas \& Betts Corp., 188 F.3d 153, 158 (3d Cir. 1999) ("When an employer makes decisions about the design of a welfare plan, such as a severance plan, it functions as an employer and not as an administrator and thus it is not acting as a fiduciary.") (emphasis added).

${ }^{35}$ See 29 U.S.C. $\& 1104(A)(1)(B)$. See generally Jones v. Harris Assocs., $130 \mathrm{~S}$. Ct. $1418,1428-29$ (2010) (asserting that if a fee is so disproportionately large, that it bears no reasonable relationship to the services rendered that the fees could not have been negotiated at arms length); Braden v. Wal-Mart Stores, Inc., 588 F.3d 585, 59596 (8th Cir. 2009) (finding excessive fees where management of employee retirement plan offered only shares that charged significantly more than others). 
the common law of trusts. ${ }^{36}$ The key to meeting the prudent person standard is proper investigation into investment options. ${ }^{37}$ Fiduciaries can avoid many of their prudent investor responsibilities by granting employees control over asset selection within the defined contribution plan. $^{38}$

ERISA addresses a wide array of plan types, including both pension and welfare plans. ${ }^{39}$ Thus, ERISA applies to employee benefits both inside and outside retirement - both the welfare benefits provided by the employer to the employee during the course of employment as well as the pension benefit of compensation that is triggered when the employee retires. On the retirement side, ERISA is primarily concerned with the financial side of retirement savings such as contributions, vesting, fiduciary duties, and participation. This Article discusses $\S 401(\mathrm{k})$ plans and § 403(b) plans. Section 401(k) plans and $\S 403$ (b) plans are pension plans that allow workers to contribute before-tax dollars towards retirement and to direct where those dollars

36 See Firestone Tire \& Rubber Co. v. Bruch, 489 U.S. 101, 110 (1989) (confirming that principles of the law of trusts govern ERISA fiduciary duties); see also Fink v. Nat'l Sav. \& Trust Co., 772 F.2d 951, 955 (D.C. Cir. 1985) ("Prudence under ERISA is measured according to the objective prudent person standard developed in the common law of trusts. A court's task in evaluating fiduciary compliance with this standard is to inquire "whether the individual trustees, at the time they engaged in the challenged transactions, employed the appropriate methods to investigate the merits of the investment and to structure the investment."') (citing Donovan v. Mazzola, 716 F.2d 1226, 1232 (9th Cir. 1983)).

${ }^{37}$ Fink, 772 F.2d at 957 ("A fiduciary's independent investigation of the merits of a particular investment is at the heart of the prudent person standard."). The burden of monitoring many investments for both financial integrity and excessive fees might dampen the urge to add investment alternatives to the retirement plan. Yet the same fiduciary duties that argue against having many investment options also encourage a wide range of investment choices. See, e.g., Braden, 588 F.3d at 596-602 (using the employer's decision to limit the pension plan's investment options to support a charge of imprudent management).

${ }_{38}$ See In re Unisys Sav. Plan, 74 F.3d. 420, 443-45 (3d Cir. 1995) (recognizing that a fiduciary may be excused from liability due to participant's exercise of control over investment under ERISA provision).

39 ERISA applies to both pension plans and welfare plans. A program that defers compensation until termination or retirement is a pension plan. ERISA $\S 3(2)(\mathrm{A}) ; 29$ U.S.C. \& 1002(2) (2012). A welfare program provides specified benefits such as medical, surgical, or hospital care or benefits; or benefits in the event of sickness, accident, disability, death or unemployment; or vacation benefits, apprenticeship or other training programs, or day care centers, scholarship funds, or prepaid legal services. See 29 U.S.C. § $1002(1)$; see also WIEDENBECK, supra note 17, at 8-9 (explaining that within ERISA qualified pension plans, there are defined benefit plans and defined contribution plans. Defined benefit plans give a guaranteed retirement payment. Defined contribution plans provide a set contribution but the payment depends on how well the contributed monies performed as investments over time.). 
are invested within an employer limited universe of options. The plans are named after the sections that create them in the Internal Revenue Code. ${ }^{40}$

ERISA directly addresses discrimination in employee benefits and pensions based on age and income. ${ }^{41}$ However, ERISA's rules do not directly address other types of discrimination covered by Title VII, such as sex, color, race, or national origin. Nevertheless, the rules for qualifying a pension plan under ERISA are meant to make pensions widely available. Further, as discussed below, the Supreme Court has read Title VII's non-discrimination protections into ERISA. ${ }^{42}$

\section{B. ERISA and the Equal Employment Opportunity Act (Title VII)}

As noted above in Part I.A, ERISA clearly prohibits discrimination in employee benefits based on age and income. A completely separate statute - Title VII - governs workplace discrimination based on race, sex, color, religion, or national origin..$^{43}$ In City of Los Angeles Department of Water and Power v. Manhart and Arizona Governing Committee v. Norris, the Supreme Court addresses sex discrimination and pension benefits. ${ }^{44}$ Gilbert v. General Electric Co. concerns

40 Two sections of the Internal Revenue Code allow employees to participate in specific retirement savings plans wherein contribution to the plan as well as the interest and earnings accumulated are tax-deferred. The $401(\mathrm{k})$ plan may be offered by for-profit organizations like businesses and corporations. See Alyssa Fetini, A Brief History of: The 401(k), TIME, Oct. 16, 2008, available at http://www.time.com/ time/magazine/article/ 0,9171,1851124,00.html; see also DEPT. OF THE TREAS., INTERNAL Revenue Serv., Publication 560, Retirement Plans for Small Business 4 (2012), available at http://www.irs.gov/pub/irs-pdf/p560.pdf. The 403(b) plan may be offered by non-profit organizations, such as universities and some charitable organizations. See A Short History of 403(b) Plans, PENsions AND INVESTMENTS, http://www.pionline.com/misc/supplements/403b/history.html (last visited Oct. 4, 2012); see also Dept. of the Treas., Internal Revenue Serv., Publication 571, TaXSHeltered ANNuITY Plans (403(B) Plans), 2 (2012), available at http://www.irs.gov/ pub/irs-pdf/p571.pdf.

41 The Age Discrimination in Employment Act of 1967, Pub. L. No. 90-202, 81 Stat. 602 (2012) (codified as amended at 29 U.S.C. §§ 621-634) protects older workers from discrimination in employment while Treas. Reg. \& 1.401(a)(4) (2001) provides guidelines to prevent discrimination in favor of highly compensated employees, who are defined at I.R.C. $\$ 414(q)$.

42 See generally I.R.C. \& $410(\mathrm{a})(\mathrm{l})(\mathrm{A})$ (stating age restrictions); I.R.C. $\$ 410(\mathrm{a})(\mathrm{l})(\mathrm{B})$ (stating years of service restrictions); I.R.C. \& $410(\mathrm{~b})(1)(\mathrm{A})$ (giving ratio test for plan coverage); I.R.C. \& $410(\mathrm{~b})(2)(\mathrm{A})$ (presenting average benefit percentage test).

43 See 42 U.S.C. $\$ 2000$ e-2 (2012) (discussing unlawful employment practices).

44 L.A. Dep't of Water \& Power v. Manhart, 435 U.S. 702, 717 (1977) (concluding that a requirement that female employees make larger contributions to the pension 
pregnancy discrimination in a welfare plan. ${ }^{45}$ These cases make clear that Title VII's protections are read into employee benefits and retirement systems, including ERISA qualified plans.

\section{Manhart and Norris - Sex Discrimination and Pensions}

City of Los Angeles Department of Water and Power v. Manhart challenged an employer-sponsored pension plan that paid equal retirement benefits to men and women but charged women larger retirement contributions. ${ }^{46}$ The employer justified making females pay almost $15 \%$ more in order to receive the same retirement benefits as males based on greater female longevity. ${ }^{47}$ Both the District Court and the Court of Appeals agreed that a sexual distinction in retirement contributions is an unlawful employment practice under Title VII. ${ }^{48}$

fund than male employees violated $\S 703(a)(1)$ of Title VII, which makes it unlawful for an employer to discriminate against an individual because of the individual's sex).

45 Gilbert v. Gen. Elec. Co, 429 U.S. 125, 133-46 (1976) (finding that a disability benefit plan does not violate Title VII because it excludes coverage of pregnancyrelated disabilities).

46 The required monthly contributions to the fund by female employees were $14.84 \%$ higher than the contributions required of comparable male employees. See Manhart, 435 U.S. at 705.

47 Id. The Department's study of mortality tables showed females would live a few years longer than males; thus, the pension cost for the average female would be greater than that of males as more monthly payments would be made.

48 See Manhart v. L. A. Dep't of Water \& Power, 553 F.2d 581, 590-91 (9th Cir. 1976) (agreeing with the District Court that the clear policy behind Title VII is requiring each employee be treated as an individual; thus, setting retirement contributions rates solely on the basis of sex is forbidden); Manhart v. L.A. Dep't of Water \& Power, 387 F. Supp. 980, 983-84 (C.D. Cal. 1975) (noting that in passing Title VII, Congress established a policy wherein each person must be treated as an individual and not on the basis of general characteristics).

Title VII discusses unlawful employment practices:

703(a). UNLAWFUL EMPLOYMENT PRACTICES

(a) Employer practices

It shall be an unlawful employment practice for an employer -

(1) to fail or refuse to hire or to discharge any individual, or otherwise to discriminate against any individual with respect to his compensation, terms, conditions, or privileges of employment, because of such individual's race, color, religion, sex, or national origin; or

(2) to limit, segregate, or classify his employees or applicants for employment in any way which would deprive or tend to deprive any individual of employment opportunities or otherwise adversely affect his 
Arizona Governing Committee v. Norris is Manhart's financial mirror. In Norris, male and female employees paid the same amounts into their retirement accounts, but females received lower retirement benefits. ${ }^{49}$ Just as the courts found that Title VII does not tolerate charging females more for the same retirement benefits, the District Court, the Court of Appeals, and the Supreme Court all found that Title VII prohibits providing female employees with smaller benefits in exchange for the same retirement contributions. ${ }^{50}$

\section{Gilbert v. General Electric - Sex Discrimination and Welfare Plans}

In Gilbert v. General Electric Co., the employer-sponsored short term disability plan excluded pregnancy coverage. ${ }^{51}$ The District Court and the Court of Appeals agreed that excluding pregnancy from the plan's benefits was unlawful sex discrimination under Title VII. ${ }^{52}$ When the Supreme Court disagreed and allowed the lack of pregnancy coverage to survive attack, ${ }^{53}$ Congress passed the Pregnancy Discrimination Act

status as an employee, because of such individual's race, color, religion, sex, or national origin.

42 U.S.C. \& $2000(\mathrm{e})$.

49 Ariz. Governing Comm. v. Norris, 463 U.S. 1073, 1081-86 (1983) (holding that "the classification of employees on the basis of sex is no more permissible at the payout stage of a retirement plan than at the pay-in stage.").

so See id.; see also Ariz. Governing Comm. v. Norris, 671 F.2d 330, 333 (9th Cir. 1982) (affirming that an employer may not offer a fringe benefit which treats an individual woman differently than an individual man); Norris v. Ariz. Governing Comm., 486 F. Supp. 645, 652 (D. Ariz. 1980) ("Any discrimination against a female employee in respect to compensation, condition of employment, or privilege of employment solely because of her sex is a violation of Title VII . . . smaller monthly annuity payments to a female employee than to a male employee contributing the same amount, is discriminatory and in violation of Title VII of the 1964 Civil Rights Act.").

51 Gilbert v. Gen. Elec. Co., 375 F. Supp. 367, 372 (E.D. Va. 1974) (stipulating Fact 29, "benefits under weekly sickness and accident insurance will not be payable for any absence due to pregnancy, resulting childbirth or to complications in connection therewith").

52 Gilbert v. Gen. Elec. Co. 519 F.2d 661, 667 (4th Cir. 1975) (agreeing that denying pregnancy-related disability from the disability employee benefit programs is prohibited by Title VII); Gilbert, 375 F. Supp. at 385-86 (holding that denial of pregnancy-related disability benefits is prohibited by Title VII). But see Gen. Elec. Co. v. Gilbert, 429 U.S. 125, 133-146 (1976) (finding employer's disability benefits plan does not violate Title VII because of its failure to cover pregnancy-related disabilities).

53 Gilbert, 429 U.S. at 133-46. The Court followed its reasoning in Geduldig v. Aiello, 417 U.S. 484 (1974), where a California disability insurance program's denial of benefits for pregnancy-related disabilities was found not to violate the Fourteenth 
of 1978, making discrimination based on pregnancy an unlawful employment practice under Title VII. ${ }^{54}$ Pregnancy leave is a type of welfare plan benefit that ERISA covers in addition to pensions.

\section{The Equal Employment Opportunity Act (Title VII) and Religious Accommodation}

Title VII applies to most employers, public and private..$^{55}$ Title VII's basic purpose is to prohibit discrimination in hiring and employment on the basis of race, national origin, color, religion, and sex. ${ }^{56}$ Under

Amendment. Justice Rehnquist's majority opinion pointed out that the plan in question paid out about as much money to female as to male claimants, and that pregnancy differed from other conditions not just because only women became pregnant but also because it is often "voluntarily undertaken and desired." See Gilbert, 429 U.S. at 133-46. Justice Rehnquist relied on language from Geduldig, in which Justice Stewart argued that when only pregnant women and nonpregnant persons (including men) were involved, there was no gender discrimination. See id.

54 The Pregnancy Discrimination Act, Pub. L. No. 95-555, 92 Stat. 2076 (1978) (codified as amended at 42 U.S.C. \& $2000 \mathrm{e}(\mathrm{k})(2012)$ ) added to the definition of "because of sex" and "on the basis of sex" in $\$ 701$ :

(k) The terms 'because of sex' or 'on the basis of sex' include, but are not limited to, because of or on the basis of pregnancy, childbirth, or related medical conditions; and women affected by pregnancy, childbirth, or related medical conditions shall be treated the same for all employment-related purposes, including receipt of benefits under fringe benefit programs, as other persons not so affected but similar in their ability or inability to work, and nothing in section $703(\mathrm{~h})$ of this title shall be interpreted to permit otherwise. This subsection shall not require an employer to pay for health insurance benefits for abortion, except where the life of the mother would be endangered if the fetus were carried to term, or except where medical complications have arisen from an abortion: Provided, That nothing herein shall preclude an employer from providing abortion benefits or otherwise affect bargaining agreements in regard to abortion.

55 See Coverage, U.S. Equal Emp. OPPORTUnity COMmission, http://www.eeoc.gov/ employers/coverage.cfm (last visited Sept. 15, 2012).

56 See 42 U.S.C. \& 2000e-2(a) (2012). In relevant part, \$ 2000e-2(a) describes employer practices:

It shall be an unlawful employment practice for an employer -

(1) to fail or refuse to hire or to discharge any individual, or otherwise to discriminate against any individual with respect to his compensation, terms, conditions, or privileges of employment, because of such individual's race, color, religion, sex, or national origin; or

(2) to limit, segregate, or classify his employees or applicants for employment in any way which would deprive or tend to deprive any individual of employment opportunities or otherwise adversely affect his 
Title VII, religion includes observance and practice as well as belief. Thus, Title VII monitors more than hiring and promotion. The statute also requires employers to reasonably accommodate religious observance and practice. ${ }^{57}$

\section{EEOC Creates Religious Accommodation}

Originally, Title VII only addressed religious discrimination in the workplace. ${ }^{58}$ The statute did not go on to require religious accommodation. $^{59}$ TheEEOC introduced the idea of religious accommodation in its 1967 rules directing employers: "to make reasonable accommodations to the religious needs of employees and prospective employees where such accommodations can be made without undue hardship on the conduct of the employer's business." 60

\section{Supreme Court Rejects Religious Accommodation}

Some years after the EEOC introduced its religious accommodation regulations, the Supreme Court was faced with its first religious accommodation decision when it found that Reynolds Metals Company was within its rights to fire Kenneth Dewey rather than work around Mr. Dewey's religious requirements. ${ }^{61} \mathrm{Mr}$. Dewey worked

status as an employee, because of such individual's race, color, religion, sex, or national origin.

5742 U.S.C. \& 2000e (2012) ("The term 'religion' includes all aspects of religious observance and practice, as well as belief, unless an employer demonstrates that he is unable to reasonably accommodate to an employee's or prospective employee's religious observance or practice without undue hardship on the conduct of the employer's business.").

${ }^{58}$ See Dewey v. Reynolds Metals Co., 429 F.2d 324, 328 (6th Cir. 1970). The original statute at 42 U.S.C. $\$ 2000 \mathrm{e}-2$ (a) read:

(a) It shall be an unlawful employment practice for an employer-

(1) to fail or refuse to hire or to discharge any individual, or otherwise discriminate against any individual with respect to his compensation, terms, conditions, or privileges of employment, because of such individual's race, color, religion, sex, or national origin.

The Sixth Circuit also referred to the legislative history of the Title Vll in support of the majority's view that the statute was only aimed at discriminating practices. See Dewey, 429 F.2d at 328.

59 See H.R. 1746 (1972), reprinted in LEGISLATIVE HISTORY OF THE EQUAL EMPLOYMENT OPPORTUNITY ACT OF 1972, at 711-715 (1972).

6029 C.F.R. \& 1605.1 (2012)

61 See Dewey v. Reynolds Metals Co., 402 U.S. 689, 689 (1971) (showing an equally divided Court that affirmed the Sixth Circuit reversal of the District Court; 
a shift that required Sunday overtime. When he became a Sabbatarian, Mr. Dewey at first arranged coverage with other team members; but soon Reynolds Metals supervisors began pressuring Mr. Dewey's coworkers to stop accommodating him, and Mr. Dewey began believing that asking others to work on Sunday was doctrinally improper. In the end, Reynolds Metals fired Mr. Dewey who then began seeking accommodation for his Sabbatarian practice from other sources including from his union and the federal courts. ${ }^{62}$

Only the District Court agreed with Mr. Dewey that Reynolds Metals acted outside its rights. ${ }^{63}$ In fact, the Supreme Court's decision in Dewey v. Reynolds Metals merely confirms the Sixth Circuit's conclusion that: (1) the Title VIl of that time only reached discrimination, not accommodation; (2) Reynolds Metals did not discriminate against Dewey; and (3) Dewey had refused Reynolds Metals' reasonable accommodation. ${ }^{64}$

\section{Congress Requires Religious Accommodation}

In response to Dewey, the Sabbatarian Senator Jennings Randolph (D-WV) introduced an amendment to Title VII which he hoped would "... assure that freedom from religious discrimination in the employment of workers is for all time guaranteed by law." ${ }^{65}$ That amendment added a definition of religion to Title VII that echoed the earlier EEOC rules:

(j) The term "religion" includes all aspects of religious observance and practice, as well as belief, unless an employer demonstrates that he is unable to reasonably accommodate to an employee's or prospective employee's religious observance

Justice Harlan did not participate).

${ }^{62}$ Dewey v. Reynolds Metals Co., 300 F. Supp. 709, 710-11 (W.D. Mich. 1969) (referencing established facts).

${ }^{63}$ Id. at 712-15 (holding that the company rule of requiring employees to work on Sunday or to find a substitute employee forced employee, who did not believe in working on Sunday or encouraging others to work on Sunday, to choose between his religion and his job; thus the rule was discriminatory in its effect in violation of the Civil Rights Act).

64 Dewey, 429 F.2d at 331 (holding that the employer's allowance of employee finding a substitute to work the shift so that employee could observe his Sabbath was a reasonable accommodation to meeting his religious needs).

65 See H.R. 1746 (1972), reprinted in LEGISLATIVE HISTORY OF THE EQUAL EMPLOYMENT OPPORTUNITY ACT OF 1972, at 712 (1972). 
or practice without undue hardship on the conduct of the employer's business. ${ }^{66}$

In general, courts have chosen to find the legislative history surrounding Senator Randolph's amendment vague and unpersuasive. ${ }^{67}$

\section{The Supreme Court Refuses to Enforce Religious Accommodation}

Both of the Supreme Court's two religious accommodation decisions after Senator Randolph's amendment to Title VII's definition of religion relate to Sabbatarian accommodation. In each instance, the Court turned a congressional mandate into a polite suggestion. ${ }^{68}$

Trans World Airlines v. Hardison illustrates Title VII's undue business hardship defense to reasonable accommodation. The undue

$66 \quad 42$ U.S.C. $\$ 2000$ e (2012).

${ }^{67}$ See Trans World Airlines v. Hardison, 432 U.S. 63, 74-75, n.9 (1977) (indicating that the legislative history and Senator Jennings' remarks are of little assistance in determining the degree of accommodation required of an employer or under what circumstances "reasonable accommodation" must be made).

68 See Ansonia Bd. of Educ. v. Philbrook, 479 U.S. 60, 69 (1986) (determining that an employer has met the obligation . . . when it demonstrates it has offered a reasonable accommodation to the employee"); Hardison, 432 U.S. at 79 (holding that the duty to accommodate did not require the employer "to take steps inconsistent with the otherwise valid [collective-bargaining] agreement"). See generally Marc Galanter, Religious Freedoms in the United States: A Turning Point?, 1966 WIS. L. REV. 217 (1966) (explaining that courts reject the notion that there is any preferment involved but there is a problem with the relationship between neutrality and religious differences); Michael W. McConnell, Accommodation of Religion, 1985 SUP. CT. REV. 1, 26-28 (1985) (discussing accommodation of religion generally and stating the purpose of religious accommodation is to relieve the believer from the conflicting claims of religion and society); James M. Oleske, Jr., Federalism, Free Exercise, and Title VII: Reconsidering Reasonable Accommodation, 6 U. PA. J. CONST. L. 525, 530 (2004) (developing the argument that Title VII's reasonable accommodation provision is appropriate enforcement legislation); Barbara J. Redman, Sabbatarian Accommodation in the Supreme Court, 33 J. CHURCH \& ST. 495 (1991) (showing the inconsistency of the Court in its protection of religious free exercise and of Sabbatarians in particular, finding the cases reinforce the status quo which favors the majority religion); Michael E. Smith, The Special Place of Religion in the Constitution, 1983 SUP. CT. REV. 83 (1983) (discussing religion and the Constitution and recognizing the conflict religion places in interpreting the Free Exercise Clause and the Establishment Clause); Dean B. Ziegel, Prohibition of Religious Observances in the Workplace, 5 HOFSTRA LAB. L. J. 197, 215 (1987-1988) (concluding that a "nation that values religious pluralism and the safeguard of the freedom to exercise these beliefs, cannot compel minority religions to choose between their faith and their daily bread." Thus Congress mandated reasonable accommodation by employers without undue hardship to the employers.). 
business hardship defense arises when the employer has not reasonably accommodated the employee's religious practice or observance ${ }^{69}$ A successful undue business hardship defense releases the employer from the obligation to accommodate. ${ }^{70}$

Mr. Hardison was a Sabbatarian whose union balked at allowing him to bypass its seniority system in order to secure a Saturday-free work schedule and whose employer claimed undue hardship in the face of his request for Saturday coverage. ${ }^{71}$ The Supreme Court found that both Mr. Hardison's union and his employer would suffer undue hardship from accommodating Mr. Hardison's request for a Saturdayfree work schedule and that this undue business hardship justified TWA's decision to terminate Mr. Hardison: to require TWA to bear more than a de minimis cost in order to give Hardison Saturdays off was an undue hardship. ${ }^{72}$

Ten years after Hardison, the Supreme Court explained in Ansonia Board of Education v. Philbrook that the employer's preferred accommodation is the employee's only alternative in a Title VII religious accommodation claim. ${ }^{73} \mathrm{Mr}$. Philbrook was a teacher who missed six school days a year because of his religious practice. Mr.

69 See Ansonia, 479 U.S. at 68; see also United States v. Bd. of Educ. for Sch. Dist. of Phila., 911 F.2d 882, 901 (3d Cir. 1990).

70 See Ansonia, 479 U.S. at 68; Hardison, 432 U.S. at 84-85; EEOC v. Firestone Fibers \& Textiles Co., 515 F.3d 307-14 (4th Cir. 2008) (holding that employer satisfies its duty to accommodate by either providing reasonable accommodation or showing undue business hardship).

71 See Hardison, 432 U.S. at 76-78.

72 Id. at 84-85. The Court further determined that:

Like abandonment of the seniority system, to require TWA to bear additional costs when no such costs are incurred to give other employees the days off that they want would involve unequal treatment of employees on the basis of their religion. By suggesting that TWA should incur certain costs in order to give Hardison Saturdays off the Court of Appeals would in effect require TWA to finance an additional Saturday off and then to choose the employee who will enjoy it on the basis of his religious beliefs. While incurring extra costs to secure a replacement for Hardison might remove the necessity of compelling another employee to work involuntarily in Hardison's place, it would not change the fact that the privilege of having Saturdays off would be allocated according to religious beliefs.

Justice Marshall's dissenting opinion found the District Court's record and findings did not support undue hardship for the employer. But see id. at 91-97. Justice Marshall observed a finding that "TWA, one of the largest air carriers in the Nation, would have suffered undue hardship ... defies both reason and common sense." Id. at 91-92.

73 See Ansonia, 479 U.S. at 68-69 ("We accordingly hold that an employer has met its obligation ... when it demonstrates that it has offered a reasonable accommodation to the employee."); see also Hardison, 432 U.S. at 84-85. 
Philbrook's union contract allowed three days of religious leave along with additional personal and sick days that were not allowed for religious purposes. Mr. Philbrook took his three days of annual religious leave each year and made up his extra three days of observance through scheduled hospital visits, absences without excuse, or work in defiance of his religious obligations. ${ }^{74}$

The Board of Education rejected Mr. Philbrook's request to apply either his personal or his sick days to religious leave or, in the alternative, to pay $\mathrm{Mr}$. Philbrook for his three days of additional absence while also offsetting his wages by the cost of covering his classes during his extra three days of religious observance. ${ }^{75}$ The Supreme Court upheld the Board of Education's refusal to consider Mr. Philbrook's alternative requests for religious accommodation and wrote instead:

We find no basis in either the statute or its legislative history for requiring an employer to choose any particular reasonable accommodation. By its very terms the statute directs that any reasonable accommodation by the employer is sufficient to meet its accommodation obligation. ${ }^{76}$ Apparently, the three days paid leave Philbrook and his colleagues already received for religious observance were accommodation enough.

As one would expect, the lower federal courts follow the Supreme Court's applications of "undue hardship" and "reasonable accommodation" under Title VII. For example, several authors note that lower federal courts find undue hardship in any religious accommodation that involves financial cost. ${ }^{77}$

74 Ansonia, 479 U.S. at 63-64.

75 Id. at 64-65.

76 Id. at 68. See generally Debbie N. Kaminer, Title VII's Failure to Provide Meaningful and. Consistent Protection of Religious Employees: Proposals for an Amendment, 21 BERKELEY J. EMP. \& LAB. L. 575, 592-97 (discussing Ansonia and its background in detail).

77 See Keith S. Blair, Better Disabled than Devout? Why Title VIl has Failed to Provide Adequate Accommodations Against Workplace Religious Discrimination, 63 ARK. L. REv. 515, 538-44 (2010) (concluding that undue hardship standard defense for reasonable accommodation for religion under Title VII is employer focused); Friedman, supra note 7 , at $155-60$ (determining that any monetary cost to the employer is a hardship that excuses accommodation); Kaminer, supra note 76 , at 621 22 (showing that lower courts almost never require an employer to take on any economic or efficiency costs in order to accommodate); Nantiya Ruan, Accommodating Respectful Religious Expression in the Workplace, 92 MARQ. L. REV. 1, 17-18 (2008) (stating lower courts generally follow a generous view of employer hardship); Peter Zablotsky, After the Fall: The Employer's Duty to Accommodate Employee Religious 


\section{Contrasting Supreme Court Pronouncements and EEOC Rules}

The EEOC's rules differ markedly from the federal courts in how they guide employers toward reasonable accommodation of religious observance and practice. Instead of deference to the employer's choice of accommodation and receptivity to the undue business hardship defense, the EEOC's rules encourage both accommodation in general and, further, accommodation based on employee preference.

Thus, for example, the regulations declare that: an employer has "an obligation to reasonably accommodate ... religious practices" and "a refusal to accommodate is justified only when an employer... can demonstrate that an undue hardship would in fact result from each available alternative method of accommodation. ${ }^{778}$ In the face of TWA $v$. Hardison's undue business hardship finding, the EEOC's rules opine

Practices under Title VII after Ansonia Board of Education v. Philbrook, 50 U. PITT. L. REV. 513, 513-15 (1989) (noting that any economic cost will result in a finding of undue employer hardship).

Two recent lower court pronouncements on religious accommodation for Sabbatarians reflect the Supreme Court's broadly pro-employer reading of the undue business hardship defense. First, the Eighth Circuit released the U.S. Postal Service from accommodating a Seventh-day Adventist, finding that excusing letter carriers from Saturday work is an undue business hardship. Harrell v. Donahue, 638 F.3d 975 , 980 (8th Cir. 2011); see Mann v. Frank, 7 F.3d 1365, 1369 (8th Cir. 1993) (finding accommodation alternatives proposed by employee to cause employer undue hardship). Second, the Middle District of Alabama granted summary judgment against a Jehovah's Witness whose co-workers' attempts to cover his Sabbath work schedule were thwarted by the employer's work rules. Berry v. MeadWestvaco Packaging Sys. LLC, No. 3:10cv78-WHA-WC, 2011 WL 867218, at *4 (M,D. Ala. Mar, 14, 2011 ).

Just as Harrell and Berry indicate that lower courts accept the Supreme Court's undue business hardship analysis, a recent Eleventh Circuit decision reproduces the Supreme Court's understanding of reasonable accommodation. In Morrissette-Brown v. Mobile Infirmary Med. Ctr., 506 F.3d 1317, 1322 (11th Cir. 2007), the Court of Appeals applied the rule that the employer selects the accommodation and upheld employment termination. The Eleventh Circuit declared:

[C]ompliance with Title VII does not require an employer to give an employee a choice among several accommodations; nor is the employer required to demonstrate that alternative accommodations proposed by the employee constitute undue hardship. Rather, the inquiry ends when an employer shows that a reasonable accommodation was afforded the employee, regardless of whether that accommodation is one which the employee suggested.

See id. (citing Beadle v. Hillsborough Cty. Sheriffs Dept., 29 F.3d 589, 592 (11th Cir. 1994)).

78 Civil Rights Act of 1964, 29 C.F.R. \& 1605.2(c) (2012) (discussing reasonable accommodation without undue hardship as required by $\S 701(\mathrm{j})$ of Title ViI). 
that Hardison is limited to "the regular payment of premium wages." 79 By considerably narrowing the Hardison decision, the rules identify "the infrequent payment of premium wages for a substitute" as a reasonable accommodation. ${ }^{80}$ In Ansonia, the Supreme Court declared that the EEOC rule stating that "when there is more than one means of accommodation which would not cause undue hardship, the employer must offer the alternative which least disadvantages the individual with respect to his or her employment opportunities" directly contravened the statute. ${ }^{81}$ In 2008, the EEOC issued additional rules regarding accommodating religion, stating that partial accommodation is not reasonable where full accommodation poses no hardship. ${ }^{82}$

\section{How Should Employers Handle Requests for Religious Accommodation?}

The sharp contrast between the statute, the Supreme Court decisions, and the EEOC rules on the question of what an employer owes an employee in the way of religious accommodation in the workplace, give the employer maximum flexibility based on its taste for litigation. Employers who wish to avoid litigation and be in complete compliance with the EEOC will follow the EEOC rules and review every reasonable alternative before determining that a religious accommodation presents an undue business hardship. Further, as between various reasonable alternatives, the employer will select the alternative that most accommodates the employee. These employers will readily adopt Sharia-compliant investments into their qualified plan options. ${ }^{83}$ Employers who are willing to take on the EEOC if challenged can rely on the Supreme Court to avoid all religious accommodation obligations. ${ }^{84}$

But even the most risk taking employer should consider that the Court has never faced a religious accommodation request made

7929 C.F.R. \& $1605.2(\mathrm{e})(1)$.

80 Id.

81 Ansonia Bd. of Educ. v. Philbrook, 479 U.S. 60, 69, n.6 (1986) (holding that EEOC guideline that requires employer to choose the religious accommodation that least disadvantages an individual's employment opportunities is inconsistent with plain meaning of $\S 701(j)$ of Civil Rights Act of 1964 to extent that it requires employer to accept any alternative favored by employee short of undue hardship); see 29 C.F.R. \& 1605.2(c) (discussing reasonable accommodation).

${ }_{82}$ EQUAL EMPLOYMENT OPPORTUNITY COMM'N, supra note 8, at 54.

83 See supra Part I.C.1.

${ }^{84}$ See supra Part I.C.2. 
against the background of a substantial tax benefit. We know that when Congress asks for religious accommodation from the employer but gives nothing in return, the Court rejects the employer's obligation to accommodate unless the accommodation is cost free. ${ }^{85}$ The question then is what is Congress's power to demand employer compliance when its requested religious accommodation is wedded to a tax subsidy?

\section{ISLAMIC LAW AND THE CONNECTION BETWEEN RELIGION AND PENSION INVESTMENT}

Congress has decided to invest billions of dollars in private pensions for the benefit of millions of workers. Employees who participate in private pensions invest their before-tax dollars in investment vehicles selected by their employers. These employer-selected investment options are forbidden to Muslims primarily because Islamic law prohibits the giving or taking of interest. ${ }^{86}$

Muslim workers could participate in their employer-provided pension plans through the religious accommodation of adding Shariacompliant investments to their qualified plan investment options. Under present Title VII jurisprudence, such employer-provided religious accommodation appears entirely voluntary. This Article argues that in the pension plan context employer accommodation is not voluntary. Instead, religious accommodation is required in exchange for the tremendous tax benefit conferred on the ERISA qualified plan.

\section{A. Islamic Law as Religious Law}

Americans are often confused about Islamic observance and practice. ${ }^{87}$ Nowhere is this confusion more evident than in regard to Islamic law. Unlike state-centered law, Islamic law is religious law. ${ }^{88}$

85 See supra Part I.C.4.

86 See M. Umer Chapra, Why Has Islam Prohibited Interest? Rationale Behind the Prohibition of Interest, in INTEREST IN ISLAMIC ECONOMICS: UNDERSTANDING RIBA 96 98(Abdulkader Thomas ed., 2006).

87 See generally Marie A. Failinger, Islam in the Mind of American Courts: 1800. 1960, 32 B.C. J.L. \& SoC. Just. 1 (2012) (exploring the ways that American judges use often incorrect notions of Muslims to justify their conclusions, thus highlighting the existing stereotypes and insensitivities).

88 See WaEl B. HallaQ, AN Introduction to Islamic LaW 14-19 (2009) [hereinafter Hallaq, Introduction]; WaEl B. Hallaq, SHari'A: Theory, Practice, Transformations 5-6 (2009) [hereinafter HallaQ, Sharia Theory]; Mark E.

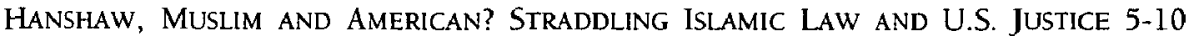


As religious law, Islamic law controls Muslims' lives and actions wherever they live and whatever their secular obligations. ${ }^{89}$ In this sense, Islamic law is like Rabbinic or Canon law: it travels with the believer across national and legal boundaries. ${ }^{90}$

Theologically, Islamic law differs from Canon law and Rabbinics in that the Muslim tradition accepts the Quran as the direct word of God transcribed by the Prophet Mohammed without error. ${ }^{91}$ Yet, the three Abrahamic traditions share many common aspects. Although the general view in the West is that neither Christianity nor Judaism restricts its members' investment options, Muslims are not alone in facing religious restrictions on their economic activities.

In fact, the more devout the Christian or Jew, the more likely a conflict between tax benefit and faith - Canon law still prohibits usury, and Roman Catholics remain subject to restrictions on charging excessive interest. ${ }^{92}$ Roman Catholic Bishops, including the present

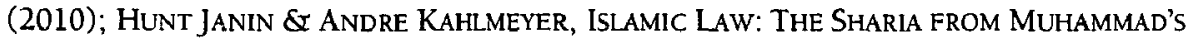
Time to the Present 1-5 (2007); Mohammad Hashim Kamali, Shari'ah Law: AN INTRODUCTION 1-13 (2008).

89 See generally Kilian Balz, SHARIA RiSK? How ISLAMIC FinANCE Has TRANSFORMED ISLAMIC CONTRACT LAW (2008) (developing the theory that Islamic finance is not exclusively an "application of Islamic law" but rather a contractual practice that evolved in international finance), available at http://www.law.harvard.edw/ programs/ilsp/publications/balz.pdf; HALLAQ, SHARIA THEORY, supra note 88 providing an overview of to the history and evolution of Sharia); KAMALI, supra note 88 (providing a comprehensive introduction to Shari'a Law, and examining the sources, characteristic features, and various schools of thought of a system often stereotyped for its severity); Kathleen M. MoOre, The Unfamiliar abode: IsLamic LaW IN THE UNITED STATES AND BRITAIN (2010) (examining the ways in which diasporic Muslim communities may utilize religious jurisprudence and other tools to ensure the continued relevancy of their faith even within the context of social settings that impose unique social demands, also, questioning whether the pluralistic environment of modern America will itself be altered by the presence of Muslims or whether pluralism will demand a "modernized" and reformed Islam); JOSEPH SCHACHT, AN INTRODUCTION TO ISLAMIC LAW (1964) [hereinafter SCHACHT, INTRODUCTION] (presenting a broad account of the current knowledge of Islamic history and outlining the system of Islamic law); JOSEPH SCHACHT, ORIGINS OF MUHAMMADAN JURISPRUDENCE (1950) [hereinafter SCHACHT, ORIGINS] (concluding, as the European scholar to offer a comprehensive history of early Islamic law, that Islamic law had not always been based on the prophetic hadith, and proposes that opinions of eighth century jurisprudents were first attributed to Followers, then Companions, and lastly to the Prophet).

90 See MOORE, supra note 89 , at 1-10.

91 See HALLAQ, INTRODUCTION, supra note 88, at 16; HALLAQ, SHARLA THEORY, supra note 88 , at $32-33$; JANIN \& KAHLMEYER, supra note 88 , at 2; KAMALI, supra note 88 , at 2-3; SCHACHT, INTRODUCTION, supra note 88, at 10-14; SCHACHT, ORIGINS, supra note 89, at 53.

92 See Thomas Storck, Is Usury Still A Sin?, 36 COMMUNIO: INT'L CATH. REv. 447, 468 (2009), available at http://www.secondspring.co.uk/economy/StorckUsury.pdf 
Pope Benedict XVI, direct Catholics to consider such issues as abortion, contraception, militarism, usury, and social justice when investing. ${ }^{93}$ The Hebrew Bible contains passages that prohibit usury, particularly when interest is charged to relatives or others to whom protection and charity is owed. ${ }^{94}$

Like Canon law and Rabbinics, Islamic law has specific rules regarding financial transactions. ${ }^{95}$ Unlike many twenty-first century Western Christians and Jews, however, Western Muslims are more likely to follow their religion's financial teachings and accordingly refrain from non-compliant investment options. Muslims are more likely to take interest seriously because Islamic law takes a more restrictive view toward interest than modern Christianity or Judaism does. Christianity and Judaism now accept interest while still prohibiting usury, whereas Islam continues to prohibit interest in all transactions no matter the rate.

(stating, "Of course, it should go without saying that the interest rates ... on so-called payday ... loans, which can reach even $500 \%$ per annum, have clearly no justification in any extrinsic title, and no Catholic can lawfully have anything to do with such loans."); see also Vincent J. Cornell, In the Shadow of Deuteronomy: Approaches to Interest and Usury in Judaism and Christianity, in INTEREST IN ISLAMIC ECONOMICS: UNDERSTANDING RIBA 13-23 (Abdulkader Thomas ed., 2006).

93 See, e.g., Socially Responsible Investment Guidelines: Principles for USCCB Investments, U.S. CONF. OF CATHOLIC BISHOPS (Nov. 12, 2003), http://www.catholiclabor.org/church-doc/Invest-guidelines.htm (directing Catholic institutions away from investments that promote abortion, contraception, redlining, or military weaponry). These guidelines were first expressed in U.S. CATHOLIC BISHOPS, Economic Justice for All: Pastoral Letter on Catholic Social Teaching and the U.S. ECONOMY (1986), available at http://www.usccb.org/upload/economic justice_for_all.pdf; see also THOMAS CARSON ET AL., NEW CATHOLIC ENCYCLOPEDIA 35354 (2d ed. 2002); Letter from Pope Benedict XVI to the Bishops, Priests and Deacons, Men and Women Religious, the Lay Faithful and All People of Good Will (June 29, 2009), available at http://www.vatican.va/holy_father/benedict_xvi/encyclicals/ documents/hf_ben-xvi_enc_20090629_caritas-in-veritate_en.html (noting that "the weakest members of society should be helped to defend themselves against usury").

94 See Cornell, supra note 92, at 13-15; Constant J. Mews \& Ibrahim Abraham, Usury and Just Compensation: Religious and Financial Ethics in Historical Perspective, 72 J. Bus. ETHICS 1, 2-3 (2007) (listing Torah sections that prohibit the taking of interest and the charging of usurious rates).

95 See Chapra, supra note 86, at 97-100, 103; Wahba Al Zuhayli, The Juridical Meaning of Riba, in INTEREST IN ISLAMIC ECONOMICS: UNDERSTANDING RIBA 26-30 (Iman Abdul Rahim \& Abdulkader Thomas trans., Abdulkader Thomas ed., 2006). See generally SHAIKH MAHMUD AHMAD, SOCLAL JUSTICE IN ISLAM (Institute of Islamic Culture 1975) (acknowledging a unanimous traditional opinion that prohibits interest in Islam, and exploring whether interest in any firm is permitted and the economic impact of the abolition of interest in commerce and industry); Moshin S. Khan \& Abbas Mirakhor, Islamic Banking (Int'l Monetary Fund, Working Paper No. 91/88, 1991) (providing a brief survey of the theory and practice of Islamic banking). 


\section{B. Islamic Prohibitions Against Usury}

Although far from unique in the Abrahamic traditions, the Islamic prohibition against usury has attracted a great deal of attention and criticism from Western analysts. For years the Western critique was that the Islamic law of finance held Muslim countries and their economies hostage to pre-modern business practices. ${ }^{96}$ Recently, as the Western world faces economic collapse, the Islamic law of finance appears increasingly sound. ${ }^{97}$

For example, Islamic financial ethics oppose selling financial instruments designed to fail. ${ }^{98}$ In contrast to Western economic traditions, which encourage arm's length lender-borrower relationships, Islamic finance prefers economic partnerships where financiers maintain an economic stake in the outcome of the business activities their monies support. ${ }^{99}$ Had Goldman Sachs operated in a system that obligated equity interests in financial creations, Goldman's partners would have lost the incentive to develop and promote investments meant to fail. ${ }^{100}$

\section{Sharia-Compliant Funds}

Twenty-first century Western society considers prohibitions against interest amongst the most distinctive features of Islamic law. However, usury is only one of the many commercial practices that the Quran prohibits. ${ }^{101}$ In addition to condemning fraud and trickery, the Quran

96 See Timur Kuran, The long Divergence: How Islamic law Held Back the Middle East 279-83 (2011); Maxime Rodinson, Islam and CaPiTAlism 29, 111-12 (Brian Pearce trans., 1974).

97 See Masudul Alam Choudhury, Islamic Economics and Finance: AN EPISTEMOLOGICAL INQUIRY 274-76, 279-85, 311-13 (2011); PHILIP MOLYNeuX \& MUNAWAR IQBAL, BANKING AND FINANCIAL SYSTEMS IN THE ARAB WORLD 164-68, 218-29 (2005); Chapra, supra note 86, at 100-03.

98 Islamic banking, for example, promotes risk sharing between the provider of the funds (the investor) and the user of the funds (the entrepreneur). Both the investor and the entrepreneur share the results of the project in an equitable way. See MOLYNEUX \& IQBAL, supra note 97 , at 151.

99 See HallaQ, SHARIA THEORY, supra note 88, at 253-56; JANIN \& KaHLMEYer, supra note 88 at 171-72; KAMALI, supra note 88, at 1-13; ABDULLAH SAEED, ISLAMIC BANKING AND INTEREST: A STUDY OF THE PROHIBITION OF RIBA AND ITS CONTEMPORARY INTERPRETATION 51-73 (1996).

100 See Michael Lewis, The Big Short: InSide THE DOOMSDay Machine 143 (2010); Mark T. Williams, UnCONTROLled Risk: THE Lessons of LeHMAN BROTHERS AND How SySTEMIC RISK CAN STILl BRING DOWN THE WORLD FinANCIAL SySTEM 117-35 (2010).

101 See JANIN \& KAHLMEYER, supra note 88, at 171; RODINSON, supra note 96 , at 42 , 46, 65-75 (discussing the Islamic law of interest); SAEED, supra note 99, at 34-40. 
also forbids trading in unclean items such as wine, pigs, and animals that are not ritually slaughtered. ${ }^{102}$ Muslims have used creative lawyering for centuries in order to devise religiously acceptable transactions. ${ }^{103}$ As with Canon law and Rabbinics, Islamic law has developed means for avoiding prohibited acts while creating desired economic outcomes. ${ }^{104}$ The Christian and Jewish adaptations prohibited usury while allowing interest. The Islamic adaptation forces the lender to take a financial stake in the outcome of the transaction.

With religious legal guidance, banks and traders also find ways to accommodate Islamic law. For example, the Dow Jones Islamic Market Index tracks Islamic law compliant businesses. ${ }^{105}$ Islamic banks operating under their own religious boards occupy a growing share of the investment market. ${ }^{106}$ Large conventional banks, such as Citibank and Deutsche Bank, provide Islamic law compliant investment and

102 See JANIN \& KAHLMEYER, supra note 88, at 171; RODINSON, supra note 96, at 137.

103 See NadeEm Ul Haque \& AbBas Mirakhor, Optimal Profit-Sharing Contracts AND INVESTMENT IN AN INTEREST-FREE ISLAMIC ECONOMY 3-4 (1986); MOLYNEUX \& IQBAL, supra note 97, at 164-67; MUNAWAR IQBAL \& PHILIP MOlyneuX, THIRTY YeARS OF Islamic Banking: History, Performance and ProspeCts 105-11 (2005); Rodney Wilson, Islamic Financial Instruments, 6 ARAB L.Q. 210, 210-11 (1991).

104 See Rodinson, supra note 96, at 137-46, 188-99 (discussing transactions created under Islamic law in order to avoid the prohibition against interest). One example of a transaction that mimics interest is the sale and repurchase. The lender "sells" an item to the borrower for $\$ 120$ to be paid in one year's time. The lender then immediately repurchases the item for $\$ 100$. When the smoke clears, the lender has given the borrower $\$ 100$ and the Borrower is obligated to pay the Lender $\$ 120$ in one year's time. Mews \& Abraham, supra note 94, at 10; see also MAHMOUD A. El-GAMAL, ISLAMIC FINANCE: LAW, ECONOMICS, AND PRACTICE 86-89, $152-53$ (2007). See generally Cornell, supra note 92, at 22-23 (suggesting extension of Christian and Jewish actions to Muslims).

105 See V. Shivali, The Dow Jones Islamic Market US Index, in ISLAMIC CAPITAL MARKETS: OPPORTUNITIES AND ChALlenges 78-79 (Swapna Gopalan ed., 2009) (noting that Dow Jones created a Shariah Supervisory Board that tracks "Shariah-complaint stock globally, and constitutes the companies that are accordant with the rules of Shariah law")); see also Dow Jones Islamic Market Indices, S\&P DOW JONES INDICES, http://www.djindexes.com/islamicmarket (last visited Oct. 7,2012 ) (describing the eligibility requirements for the Dow Jones Islamic Market Index which includes "thousands of broad-market, blue-chip, fixed-income and strategy and thematic indexes that have passed rules-based screens for Shariah compliance. The indexes are the most visible and widely-used set of Shariah-compliant benchmarks in the world").

106 See Mohd Daud Bakar, Islamic Finance: InNovation and Growth 74-78 (Simon Archer \& Rifaat Ahmed Abdel Karim eds., 2002); EL-GAMAl, supra note 104, at 135-38; JANIN \& KAHLMEYER, supra note 88, at 170-74; SAEED, supra note 99, at 108118; Nabil A. Saleh, Unlawful. Gain and Legitimate Profit in Islamic law: Riba, GHARAR, AND ISLAMIC BANKING 86 (1986); Rodney Wilson, Introduction, in IsLAMIC FinANCIAL MARKETS 4-5 (Rodney Wilson ed., 1990). 
banking options. ${ }^{107}$ Other funds are available to meet Roman Catholic and other Christian investment needs. ${ }^{108}$

\section{THE SUPREME COURT'S TAX JURISPRUDENCE AND HOW IT DIFFERS FROM ITS TITLE VII ANALYSIS}

In Part $\mathrm{l}$, we saw Congress mandate religious accommodation through Title VII and the EEOC reinforce the notion of obligatory religious accommodation through its rulemaking powers. Nevertheless, in the face of an enthusiastic Congress and EEOC, the Supreme Court limits religious accommodation under Title VII to either any employer-selected reasonable accommodation ${ }^{109}$ or to almost any proof that religious accommodation brings undue business hardship. ${ }^{110}$

107 See JANIN \& KAHLMEYER, supra note 88, at 174 (discussing Islamic banking); see also Press Release, Dow Jones Indexes (Mar. 6, 2006), available at http://press.djindexes.com/?p=779. See generally DOW JONES ISLAMIC MARKET INDICES, supra note 105 (providing real-time values and charts for Sharia-compliant securities).

108 See Mews \& Abraham, supra note 94, at 11 (discussing the Ave Maria Fund, the Mennonite Mutual Aid Praxis Mutual Fund, and the Catholic Aquinas Fund).

109 See discussion supra Part I.C (discussing Title VII and religious accommodation).

110 TWA v. Hardison, 432 U.S. 63, 75, 84 (1977) (declaring that the "employer's statutory obligation to make reasonable accommodation for the religious observances of its employees, short of incurring an undue hardship, is clear," but to require the employer "to bear more than a de minimis cost, is an undue hardship").

Whether an accommodation is reasonable or an undue hardship is a matter of facts and circumstances. See United States v. N.Y.C. Transit Auth., No. 04-cv-4237, 2010 WL 3855191, at *1 (E.D.N.Y. Sept. 28, 2010) (raising factual issues as to whether religious headwear is a reasonable accommodation). District Judge Townes founded his decision in Wernick v. Fed. Reserve Bank of N.Y., 91 F.3d 379, 385 (2d. Cir. 1996) (discussing how the determination of "[w]hether or not something constitutes a reasonable accommodation is necessarily fact-specific"). Further, he looked to Borkowski v. Valley Cent. Sch. Dist., 63 F.3d 131, 138 (2d Cir. 1995) (discussing how a cost-benefit analysis is typically required), and according to Wernick, determinations are made on a case-by-case basis. Wernick, 91 F.3d at 385 (accommodating religious clothing as undue burden on school district). It seems turbans and khimars might provide reasonable accommodation for Muslim and Sikh transit workers while the same head scarfs might create undue business hardship for police, prisons, or school districts. See, e.g., Equal Emp't Opportunity Comm'n v. GEO Grp., Inc., 616 F.3d 265, 277 (3d Cir. 2010) (accommodating religious headgear is an undue burden on prison security); Webb v. City of Philidelphia, 562 F.3d 256, 258 (3d Cir. 2008) (accommodating religious headgear is an undue burden on police force); Daniels v. City of Arlington, Tex., 246 F.3d 500, 501 (5th Cir. 2001) (accommodating religious pin is an undue burden on police force); United States v. Bd. of Educ. for Sch. Dist. of Phila., 884 (3d Cir. 1990) (discussing religious garb and Title VII). 
In contrast to the Supreme Court's Title VII decisions, the Court's tax decisions paint a different picture of Congressional power. Decided one day apart, Regan $v$. Taxation with Representation of Washington and Bob Jones University $v$. United States, each bestow great weight to congressional demands. ${ }^{111}$ In both these decisions, the Court allowed Congress to force the taxpayer to give up a constitutional right in exchange for a tax benefit. In Taxation with Representation, Congress demanded the taxpayer relinquish the right to Petition Government. ${ }^{112}$ In Bob Jones University, Congress required the taxpayer give up Free Exercise of Religion.

\section{A. Tax Subsidy as Tax Expenditure}

The greater the government investment in an activity the more likely that the Supreme Court will allow Congress to impose costs on enjoyment of that activity: in South Dakota v. Dole, the State had to give up its right to control traffic within its borders; in Bob Jones University and Taxation with Representation, the taxpayers had to give up their First Amendment rights to free speech and association. Of the three decisions, South Dakota v. Dole might be the easiest to understand because the federal government made actual payments to South Dakota. How do the tax exemptions in Bob Jones University and Taxation with Representation compare to direct federal subsidies?

More than seventy years ago, Assistant Secretary of the U.S. Treasury for Tax Policy Stanley Surrey introduced the tax expenditure budget. ${ }^{13}$ Tax expenditures are the cost to the government in lost

Lower courts follow the Supreme Court's refusal to enforce more than de minimis cost accommodations, but sometimes the lower courts look favorably on no-cost accommodations such as voluntary shift swaps. See Oleske, supra note 68, at 533-34.

111 Regan v. Taxation with Representation of Wash., 461 U.S. 540, 547-48 (1984); Bob Jones Univ. v. United States, 461 U.S. 574, 602-04 (1983).

112 The Court disagreed with the claim that I.R.C. \$ 501(c)(3)'s prohibition against substantial lobbying violates the First Amendment, pointing to its decision in Cammarano v. United States, 358 U.S. 409, 513 (1959) (holding that "Congress is not required by the First Amendment to subsidize lobbying").

113 The concept of tax expenditure posits that two distinct elements comprise income tax:

The first element consists of structural provisions necessary to implement a normal income tax, such as the definition of net income, the specification of accounting rules, the determination of the entities subject to tax, the determination of the rate schedule and exemption levels, and the application of the tax to international transactions. The second element consists of the special preferences found in every income tax. These provisions, often called tax incentives or tax subsidies, are departures from the normal tax structure 
revenues that arise from tax deductions, exclusions, and credits. For example, Surrey identified tax expenditures as hidden government subsidies. ${ }^{114}$

Surrey believed that the public's lack of concern over tax expenditures reflected the Internal Revenue Code's opacity. ${ }^{115}$ In order to make taxpayers aware of tax expenditures to the same extent as direct government subsidies, Surrey convinced Congress to produce an annual tax expenditure budget. The tax expenditure budget shows the cost in revenue of significant tax benefits. ${ }^{116}$ For example, the

and are designed to favor a particular industry, activity, or class of persons. They take many forms, such as permanent exclusions from income, deductions, deferrals of tax liabilities, credits against tax, or special rates. Whatever their form, these departures from the normative tax structure represent government spending for favored activities or groups, effected through the tax system rather than through direct grants, loans, or other forms of government assistance.

Stanley S. Surrey \& Paul R. McDaniel, Tax Expenditures 3 (1985); see also Stanley S. SURREY, PATHWAYS TO TAX REFORM: THE CONCEPT OF TAX EXPENDITURES 1-29 (1973).

114 For example, Surrey queried whether Congress could politically pass a law that gave millionaires a $40 \%$ subsidy on their home mortgage interest while giving no subsidy at all to the working poor. SURREY, supra note 113, at 36-37, 232-37. Although a direct government subsidy for millionaires' housing might raise political dissent, the home mortgage interest deduction accomplishes the same economic result through the Internal Revenue Code without much protest. See I.R.C. \& 1 (2012) (stating as of June 14,2011 , the highest marginal rate is $39.6 \%$ ).

115 See SurreY, supra note 113, at 36, 326-40. See also Stanley S. Surrey and William F. Hellmuth, The Tax Expenditure Budget - Response to Professor Bitter, 22 NAT'L TAX J. 528, 533 (1969); Stanley S. Surrey, Federal Tax Policy in the 1960's, 15 BUFF. L. Rev. 477,488 (1966).

The subsidy comes from the value of the tax deduction. A tax deduction's value is based on the taxpayer's highest marginal tax rate. For most of America's working poor, their highest marginal income tax rate is $0 \%$. Thus, if a working family pays $\$ 10,000$ in mortgage interest in the year, that family will get no value from the home mortgage interest deduction. A wealthy family will have a marginal tax rate of $39.6 \%$. Each $\$ 10,000$ of mortgage interest can net that family $\$ 3,960$ in tax savings. These tax savings are then undercut by limits on the ability to use itemized deductions for high income earners. The limit of the ability of high income earners to deduct mortgage interest is a direct result of Surrey's exposure of the economic value of the home mortgage interest deduction.

116 StafF of Joint COMM. ON TAXation, 111 th CONGRess, U.S. Government PRINTING OfFICE, ESTIMATES OF FEDERAL TAX EXPENDITURES FOR FisCAL YEARS 2010-2014 (2010), available at http://jct.gov/publications.html?func $=$ startdown\&id=3718. This report addresses the definition of tax expenditures in this context:

Tax expenditures are defined under the Congressional Budget and Impoundment Control Act of 1974 (the "Budget Act") as "revenue losses attributable to provisions of the Federal tax laws which allow a special exclusion, exemption, or deduction from gross income or which provide a 
charitable contribution deduction ranks as the sixth most costly tax benefit at an annual cost of $\$ 46.8$ billion. ${ }^{117}$ In contrast, pension contributions rank as the second most costly tax benefit at an annual cost of $\$ 117.7$ billion. ${ }^{118}$

\section{B. Exchange of Constitutional Right for Government Subsidy}

\section{South Dakota v. Dole}

In South Dakota v. Dole, Congress withheld five percent of federal highway funds from South Dakota because the State permitted nineteen-year-olds to drink alcohol. ${ }^{119}$ The Supreme Court held that Congress did not act unduly coercively when it witheld the federal funds even though the penalty was triggered when South Dakota exercised its constitutional right to regulate the public welfare within its borders. Dole is one of several Supreme Court decisions that acknowledge Congress's right to demand forbearing a constitutional right in exchange for receiving a government subsidy. ${ }^{120}$

\section{Bob Jones University $v$. United States}

Bob Jones University was dedicated to teaching fundamentalist Christian beliefs, including prohibitions against interracial dating and marriage. Although not affiliated with any religious denomination, Bob Jones University was tax exempt as both an educational and a religious organization. To effectuate its religious views, Bob Jones University completely excluded "Negroes" from its student body until 1971. ${ }^{121}$ From 1971 to May 1975, the University continued to refuse applications from "unmarried Negroes," but it did accept applications from "Negroes married within their race." 122

special credit, a preferential rate of tax, or a deferral of tax liability." [citation omitted] Thus, tax expenditures include any reductions in income tax liabilities that result from special tax provisions or regulations that provide tax benefits to particular taxpayers.

Id. at 3; see also OfFice of MGMT. \& Budget, ANAlytical Perspectives: Budget of THE U.S. GOVERNMENT, FISCAL YEAR 2010, at 297-329 (2010), available at http://www.gpo.gov/fdsys/pkg/BUDGET-2010-PER/pdf/BUDGET-2010-PER.pdf.

117 Reynolds \& Steuerle, supra note 16 , at 1-8-6 to $1-8-8$.

118 Id.

119 South Dakota v. Dole, 483 U.S. 203, 203-04 (1987).

120 Id. at 207-11.

121 Bob Jones Univ. v. United States, 461 U.S. 574, 580 (1983).

122 Id. 
The university was inspired to open its admissions to married Negroes in 1971 because of Revenue Ruling 71-447. ${ }^{23}$ Based on the "national policy to discourage racial discrimination in education," Revenue Ruling 71-447 declared that "a private school not having a racially nondiscriminatory policy as to students is not 'charitable' within the common law concepts reflected in $\$ 170$ and $\S 501$ (c)(3) of the Code."124 In other words, a school that practiced race discrimination could not receive the tax benefits associated with charitable organizations such as tax exempt income and deductible charitable contributions. ${ }^{125}$

Bob Jones University challenged the government's denial of its tax exempt status, declaring that the Ruling burdened its sincerely held religious belief. Further, as Justice Rehnquist pointed out in his dissent in support of continuing the university's tax exemption, how could the Treasury impose a greater restriction on the taxpayer than Congress itself imposed in IRC $\$ 501(\mathrm{c})(3)$ ? The university met the statutory criteria for both a religious and an educational organization. ${ }^{126}$ Nevertheless, although the statute did not directly prohibit race discrimination, the Court agreed with the Service that even religious schools are not exempt charities when they practice race discrimination. ${ }^{127}$

\section{Regan $v$. Taxation with Representation}

While the Supreme Court refused mandatory religious accommodation under Title VII in Hardison and Ansonia, the same Court had no qualms about burdening a university's free exercise of religion in exchange for a government subsidy in Bob Jones University. Regan $v$. Taxation with Representation, decided one day before Bob Jones University, presents the same problem in a secular context: May Congress premise a tax exemption on the taxpayer relinquishing the

123 Rev. Rul. 71-447, 1971-2 C.B. 230 ("Both the courts and the Internal Revenue Service have long recognized that the statutory requirement of being 'organized and operated exclusively for religious, charitable, ... . or educational purposes' was intended to express the basic common law concept of 'charity'. . . All charitable trusts, educational or otherwise, are subject to the requirement that the purpose of the trust may not be illegal or contrary to public policy.").

124 Id. at 231.

125 See I.R.C. $\$ \S 170(a), 501(a), 501$ (c)(3) (2012) (whereby $\$ 501$ discusses tax exempt income and $\$ 170$ discusses deductible contribution).

126 See Bob Jones Univ., 461 U.S. at 612-23.

127 The Court determined that "to warrant exemption under $\S 501$ (c)(3), an institution must fall within a category specified in that section and must demonstrably serve and be in harmony with the public interest." Id. at 592. 
right to petition government? ${ }^{128}$ Justice Rehnquist, who advocated in favor of Bob Jones University retaining its tax exemption, delivered the Court's opinion in Taxation with Representation upholding the IRC \& 501(c)(3) limits on political speech:

Both tax exemptions and tax deductibility are a form of subsidy that is administered through the tax system. A tax exemption has much the same effect as a cash grant to the organization of the amount of tax it would have to pay on its income. Deductible contributions are similar to cash grants of the amount of a portion of the individual's contributions. The system Congress has enacted provides this kind of subsidy to nonprofit civic welfare organizations generally, and an additional subsidy to those charitable organizations that do not engage in substantial lobbying. In short, Congress chose not to subsidize lobbying as extensively as it chose to subsidize other activities that nonprofit organizations undertake to promote the public welfare. ${ }^{129}$

For Rehnquist, the difference lay in Congress express limitation on political activity as opposed to Congress's silence on race relations and tax-exempt status. Rehnquist never questioned Congress's power to deny the exercise of a constitutional right in exchange for a government subsidy. Rehnquist just required that Congress is explicit; as this Article argues, Congress is explicit in Title VII.

\section{Statutory Interpretation}

Tax expenditure adds an important dimension to the extent of religious accommodation required under Title VII. The Supreme Court agrees that the government cannot give monies to religious organizations directly in order to subsidize religious practice. ${ }^{130}$ Yet the Court allows Congress to subsidize religion through tax exemption and also to burden religion in exchange for tax exemption. ${ }^{131}$

128 Regan v. Taxation with Representation of Wash., 461 U.S. 540, 545 (1983).

129 Id. at 544.

130 See Walz v. Tax Comm'n of N.Y.C., 397 U.S. 664, 675 (1970).

131 In Walz, a New York City property owner attacked a New York State property tax exemption for houses of worship as an unconstitutional establishment of religion. Id. at 666 . Walz complained that his tax payments allowed New York to subsidize services for exclusively religious uses. Id. at 666. By a margin of eight to one, the Supreme Court disagreed and found instead that real property tax exemptions for houses of worship do not improperly establish religion. Id. at 680 . Instead, the Court 
One important goal of statutory interpretation is discovery of and adherence to legislative intent. ${ }^{132}$ Unfortunately, "legislative intent" often raises more questions than it answers. Whose intent is controlling? How can anyone speak for a mob of other people? Is intent found in the plain meaning of the statute? What if the words carry mixed meanings or meanings that have changed over time? What about committee reports? Is legislative history anti-democratic or useful illumination?

Beyond legislative intent, there is the interpretive value of stability. Where the Court has described a statute, that judicial understanding informs all future interpretations so that, over time, the statute provokes less and less controversy. ${ }^{133}$ As problems are solved, statutory stability is achieved through precedent. ${ }^{134}$ If Congress does not like the Court's interpretation, then it can override the Court by amending the statute. ${ }^{135}$

Congress did try to override the Court's view of Title VII religious accommodation. ${ }^{136}$ The amendment's sponsor, himself a Sabbatarian, introduced the inclusion of practice within the definition of religion in order to protect future Kenneth Deweys. ${ }^{137}$ Further, even before Congress's amendment of Title VII, the EEOC promulgated rules that supported the view that the statute reached religious accommodation as well as discrimination. ${ }^{138}$ Yet, when the Court faced the same facts in Trans World Airline v. Hardison that it had ruled on in Dewey $v$. Reynolds Metals, Senator Randolph's amendment to Title VII and the EEOC rules made no difference. Even as amended, the Court found that Title VII religious accommodation obligations are negated by

affirmed that states may exempt religious organizations from real property taxes without creating unconstitutional establishments. Id. at 677. In judging whether tax exemptions produce establishments of religion, four Justices offered their views on the purposes underlying the religion clauses and the appropriate tests for judging religious accommodations. $I d$. at 676-80.

132 See Lawrence M. Solan, The Language of Statutes: Laws and Their INTERPRETATION 82-119 (2010).

133 See id. at 223-30.

134 See id. at 120-59.

135 See Norman J. Singer \& J.D. Shambie Singer, Statutes and Statutory CONSTRUCIION 385-87 ( 7 th ed. 2010).

136 See discussion supra Part 1.C.3 (discussing Senator Randolph's Amendment to Title VII).

137 H.R. 1746 (1972), reprinted in LegISLATIVE History OF THE EQUAL EMPLOYMENT OPPORTUNITY ACT OF 1972 at 713 (1972).

138 See supra Part I.C.1. 
anything more than a de minimis burden on the employer's business. 139

Another value beyond legislative intent is legislative purpose. How does the statute fit within an overall framework? For example, Congress intended for ERISA qualified plans to act as a private back up to the social security retirement system. ${ }^{140}$ In order to be as effective as possible, the government subsidized private pension system must cover as many workers as possible.

The legislative purpose ideal shares much with the coherence ideal in which statutes are interpreted in harmony with one another. ${ }^{141}$ The Court has already read Title VII's prohibitions against sex discrimination into pensions through Manhart and Norris. Reading the Title VII religious accommodation provisions into pensions supports the purpose of covering as many workers as possible. The coherence ideal of reading statutes so that they work together in harmony argues for an interpretation of the employer's obligation to accommodate that expands, rather than contracts, qualified plan participation.

The Court has discussed religious accommodation under Title VII in the Sabbatarian context. Does the same meaning have to apply to religious accommodation in relation to private pension investments? Although the role of precedent in statutory interpretation is well established, it is also well established that courts sometimes do interpret the same language in the same statute differently. A group of judicial decisions may grow out of a particular political viewpoint so that the judges that share this viewpoint accept one interpretation while judges that share a different viewpoint move towards another interpretation. ${ }^{142}$ Just as groups of judges might interpret the same statute differently, the same court may apply different interpretations to the same statutory language because, for example, the court finds significant differences in the facts or the appropriate interpretive method. As illustration, Professor Tung Yin shows how different interpretive methods led the same Court to interpret the same provision of the same federal statute differently. ${ }^{143}$ Although Professor

139 See supra Part I.C.4; see also Trans World Airlines v. Hardison, 432 U.S. 63, 84 (1977); Dewey v. Reynolds Metals Co., 429 F.2d 324, 327 (6th Cir. 1970).

140 See supra Part I.A (exploring ERISA).

141 See SOLAN, supra note 132, at 129.

142 See id. at 149-52.

143 Tung Yin, Tom and Jerry (and Spike): A Metaphor for Hamdan v. Rumsfeld, the President, the Court, and Congress in the War on Terrorism, 42 TULSA L. REV. 505, 521 (2007). 
Yin abhors the Court's interpretation of the same language differently in different contexts, Professor James Blumstein advocates the use of different interpretations of the same language in the same federal statute in order to further legislative purpose. ${ }^{144}$ One point this Article makes is that the tremendous federal subsidy that undergirds the private pension system is reason enough for a court to interpret the religious accommodation rules of Title VII as more powerful when associated with ERISA than when applied to Sabbatarians. The difference in statutory interpretation when federal subsidy is involved relates to this Article's main point that although judges and courts have varying interpretations, the federal subsidy justifies a stronger interpretation of the Title VII religious accommodation rules.

\section{BORROWING FROM TAX JURISPRUDENCE: WHAT WOULD RELIGIOUS ACCOMMODATION LOOK LIKE IN THE PENSION AREA?}

We know that when Congress asks for religious accommodation from the employer but gives nothing in return, the Court rejects the employer's obligation to accommodate unless the accommodation is cost free. ${ }^{145}$ The following sections take up the question: What is Congress's power to demand employer compliance when its requested religious accommodation is wedded to a tax subsidy? The Supreme Court clearly allows Congress great power to compel private behavior, even behavior that violates religious beliefs or that forces a taxpayer to renounce constitutional rights, when the congressional mandate is

Considering the differing interpretations, the article states:

The tension between Padilla and Rasul was immediately apparent. Justice Scalia found it baffling how aliens held outside the United States could benefit from a more favorable legal rule than that applicable to a U.S. citizen. While there may be reasonable explanations for this difference in treatment, it remains that in two cases involving the same provision of the same federal statute, the Court used different interpretative methods to reach different results. More significantly, the aliens received the benefit of favorable interpretations while the citizen was saddled with the unfavorable interpretation.

Id.

144 James F. Blumstein, Defining and Proving Race Discrimination: Perspectives on the Purpose vs. Results Approach from the Voting Rights Act, 69 VA. L. REV. 633, 708-09 (1983).

${ }^{145}$ Compare supra Part I (exploring the United States Supreme Court's rejection of religious accommodation by employers where Congress offers employers no monetary incentive or benefit), with supra Part II (exploring the United States Supreme Court's enforcement of religious accommodation by employers where Congress offers employers benefits under ERISA). 
accompanied by a government subsidy. ${ }^{146}$ These tax benefits are government subsidies conferred on private pension plans putting them among the largest tax subsidies in the tax expenditure budget. ${ }^{147}$ Thus, despite the Supreme Court's anti-mandatory religious accommodation decisions toward Sabbatarians, the obligation to accommodate religious practice in the pension area is not purely voluntary under Title Vll.

Because of the great government subsidy undergirding the private pension system, the Court should follow its prior precedent and uphold the congressional mandate supporting religious accommodation in the pension plan area as it upheld restrictions on political and religious rights in exchange for tax benefit in Bob Jones University and Taxation with Representation. In other words, religious accommodation of headgear or holidays might be completely voluntary under such Supreme Court decisions as Hardison and Ansonia, because in those cases the congressional mandate was enforced through punishment rather than subsidy. In contrast, a congressional mandate for religious accommodation in a pension plan investment is no longer voluntary under Bob Jones University and Taxation with Representation. Where the congressional request is accompanied by tax benefits, the Court supports congressional power. ${ }^{148}$

The standard Title VII religious accommodation analysis is based on the interaction of Title VII and ERISA. Three basic proofs are needed to make a Title VII claim for religious accommodation: (1) sincerely held religious belief; (2) not accommodated within the ordinary course of employment; and (3) not overcome by employer defenses.

\section{A. Sincerely Held Religious Belief}

Before an employer becomes obligated to provide reasonable accommodation for religious observance or practice under Title VII, the employee must first establish a bona fide religious belief. ${ }^{149}$

146 See supra Part III.B.

147 See supra Part III.

148 See supra Part III.B.

${ }_{149}$ Tiano v. Dillard Dep't Stores, Inc., 139 F.3d. 679, 681-82 (9th Cir. 1998).The Ninth Circuit has established a two-part framework to analyze Title VII religious discrimination claims.

First, the employee must establish a prima facie case by proving that ( 1 ) she had a bona fide religious belief, the practice of which conflicted with an employment duty; (2) she informed her employer of the belief and conflict; and (3) the employer threatened her or subjected her to discriminatory 
Showing bona fide religious belief is essential because beliefs are not protected merely because they are strongly held. ${ }^{150}$ Whether or not the practice is "religious" is a facts-and-circumstances inquiry turning on the employee's motivation. ${ }^{151}$ The same practice that requires reasonable accommodation for religious observance under Title VII in one situation is not protected in other situations where the practice is engaged in for secular reasons. ${ }^{152}$

Congress takes no position on religion or religious belief in Title VII other than to state that: "The term 'religion' includes all aspects of religious observance and practice, as well as belief." 153 The EEOC Compliance Manual echoes the statute and adds that:

Religion includes not only traditional, organized religions such as Christianity, Judaism, Islam, Hinduism, and Buddhism, but also religious beliefs that are new, uncommon, not part of a formal church or sect, only subscribed to by a small number of people, or that seem illogical or unreasonable to others. .. . A belief is "religious" for Title VII purposes if it is "religious' in the person's own scheme of things," i.e., it is "a sincere and meaningful belief that occupies in the life of its possessor a place parallel to that filled by ... God." 154

treatment, including discharge, because of her inability to fulfill the job requirements. See id. Second, if the employee proves a prima facie case of discrimination, the burden shifts to the employer to show either that it initiated good faith efforts to accommodate reasonably the employee's religious practices or that it could not reasonably accommodate the employee without undue hardship.

Id. at 681-82; see also Heller v. EBB Auto Co., 8 F.3d 1433, 1438 (9th Cir. 1993); EEOC v. Hacienda Hotel, 881 F.2d 1504, 1512 (9th Cir. 1989).

150 See, e.g., Slater v. King Soopers, Inc., 809 F. Supp. 809, 809-10 (D. Colo. 1992) (dismissing religious discrimination claim by a member of the Ku Klux Klan who allegedly was fired for participating in a Hitler rally because the Ku Klux Klan is "political and social in nature" and is not a religion for Title VII purposes); Brown v. Pena, 441 F. Supp. 1382, 1385 (S.D. Fla. 1977) (holding that plaintiff's belief that eating cat food contributes to his well-being is a personal preference and not a religion); see also EQUAL EMPLOYMENT OPPORTUNITY COMM'N, supra note 8, at 8.

151 See Donna D. Page, Veganism and Sincerely Held "Religious" Beliefs in the Workplace: No Protection Without Definition, 7 U. PA. J. LAB. \& EMP. L. 363, 403-04 (2005).

152 Compare Wessling v. Kroger Co., 554 F. Supp. 548, 552 (E.D. Mich. 1982) (employer not liable where employee's church attendance was a parental and social obligation), with Redmond v. Gaf Corp., 574 F.2d 897, 904 (7th Cir. 1978) (employer liable for failing to accommodate employee's Bible classes).

153 Civil Rights Act of 1964, 42 U.S.C. \& 2000e (2012).

154 EQUAL EMPLOYMENT OPPORTUNITY COMM'N, supra note 8, at 7-8. 
To the extent that the regulations or the statute require constitutional support, the EEOC turns to United States v. Seeger (as it does in the quotation above) and Welsh $v$. United States. ${ }^{155}$ In Seeger, the Supreme Court considered a conscientious objector seeking release under a statute that required belief in a Supreme Being - a belief Seeger did not hold. ${ }^{156}$ The Court took its question as: "Does the term 'Supreme Being' ... mean the orthodox God or the broader concept of a power or being, or a faith, 'to which all else is subordinate or upon which all else is ultimately dependent?"'157 In response to its self-assigned inquiry the Court announced that "[t]he test might be stated in these words: A sincere and meaningful belief which occupies in the life of its possessor a place parallel to that filled by ... God ...."158

Welsh $v$. United States concerned the same exemption from military service that the Court addressed earlier in Seeger. The twist Welsh brought to the Seeger decision was the question whether conscientious objector status could rest on sincere moral belief absent religious faith. ${ }^{159}$ The Court declined to take Welsh at his word that his objection to war rested on moral and not religious grounds. ${ }^{160}$ Instead, the Court found that the statute did not restrict the category of conscientious objectors by "religious training and belief." ${ }^{161}$ Although the Court had previously held in Seeger that the statute required "a sincere and meaningful belief which occupies in the life of its possessor a place parallel to that filled by... God," and although Welsh professed to have no religious belief, the Court held that Welsh's moral opposition to war produced in him a corresponding "duty" to abstain from violence which "clearly entitled" him to conscientious objector status. ${ }^{162}$

\section{B. Religious Restrictions on Financial Transactions}

No matter what the definition of religion may be, Roman Catholicism and Islam clearly fall within the federal constitutional and

\footnotetext{
155 Welsh v. United States, 398 U.S. 333, 339 (1970); United States v. Seeger, 380 U.S. 163, 166 (1965) (setting forth an objective test of religious belief based on "whether a given belief that is sincere and meaningful occupies a place in the life of its possessor parallel to that filled by the orthodox belief in God").

156 Seeger, 380 U.S. at 166.

157 Id. at 174.

158 Id. at 176.

159 Welsh, 398 U.S. at 339.

160 Id at 342-43.

161 Id. at 343.

162 Id
} 
statutory safeguards for religious observance and practice. ${ }^{163}$ As discussed in Part III, one problem Muslims face is non-Muslims' lack of knowledge regarding Islamic observance and practice. ${ }^{164}$ This lack of knowledge has led to a private pension system that is essentially closed to Muslims because employer-sanctioned investment options do not take into account Islamic prohibitions against interest. ${ }^{165}$

As shown in Part III, a wide range of financial options have developed in the Muslim world to meet the requirements of the Islamic law of finance. Employers could easily add these funds to their investment portfolios with little additional expense, thereby opening their ERISA-qualified pension plans to Muslim participants. ${ }^{166}$

\section{Not Accommodated Within the Ordinary Course of Employment}

An employer acting alone cannot match the benefits ERISA gives qualified plan participants because of the enormous economic benefit that results from ERISA's substantial tax savings. Over the course of a forty year career, the difference between investing in a tax benefitted ERISA qualified plan and the monies saved in a taxed account can amount to ten years of lost salary. ${ }^{167}$ That ten years' difference in salary

163 See EQUAl EMPLOYMENT OPPORTUNITY COMM'N, supra note 8, at 6-9.

164 See generally Failinger, supra note 87 (exploring the ways in American judges use often incorrect notions of Muslims to justify their conclusions, thus highlighting the existing stereotypes and insensitivities).

165 Although some Muslims may feel free to invest in their employer plans despite the lack of Sharia-approved funds, Title VII recognizes individual faith and piety as religious expression deserving of protection, even if the faith is held by only one person. EQUAL EMPLOYMENT OPPORTUNITY COMM'N, supra note 8, at 6.

166 See supra Part II.C. See generally Dow Jones Islamic Market Indices, supra note 105 (containing a variety of Shari'ah complaint indices).

167 The following salary penalty calculation is credited to John Lighthouse. The financial benefits of participation in a 401 ( $k$ ) plan can be calculated as an equivalent percentage increase in salary, also known as the "salary penalty." The salary penalty is independent of income as long as the household income is taxed at a marginal rate of $25 \%$. We will consider the case of an employee with a $15 \%$ contribution rate and a $6 \%$ employer match, who contributes to his plan for forty years and then for the next thirty years withdraws an annuity, taxed at a $15 \%$ tax rate. The annuity grows at an annual 3\% inflation rate and there is a zero balance in the plan at the end of the thirty years. An employee who is unable to participate in the plan is assumed to save the same $15 \%$ of his salary as the participating employee during his forty year career, so that both employees would have the remaining $85 \%$ of their salary for living expenses. However, the nonparticipating employee would also have to save an additional amount equal to $25 \%$ of his salary during his forty year career in order to receive the same annuity as the participating employee. The additional amount in this example represents the salary penalty. 
is entirely explained by the tax benefits conferred on qualified plans and denied to those who cannot participate because every investment option uses aspects of interest: a common American phenomenon. The problem, and also the great redemption for the problem, is that the only way to provide the employee with ERISA's tax savings is through a qualified plan and the statutory rules for qualifying a plan address many objections to religious accommodation. ${ }^{168}$

For example, an ERISA qualified plan requires that every investment option be made available to every plan participant. ${ }^{169}$ As a result of this rule, a religious accommodation to allow Sharia-approved investments into the pension plan must provide access to those investments to every plan participant. Thus, in addition to the tremendous tax benefits that support private pension systems, another way that religious accommodation for pension plan investments is different from religious accommodation for Sabbatarians is that the only accommodation possible for qualified plan investment options benefits all plan participants equally. In contrast, Sabbatarian accommodation requires the employer to favor one employee over another based on religion. ${ }^{170}$

When we do away with the employer match, with the other factors unchanged, the salary penalty declines to $13 \%$. The $6 \%$ employer match is leveraged by the structure of the $401(\mathrm{k})$ plan and results in a $12 \%$ increase in equivalent salary.

If we increase the marginal tax rate on household income to $35 \%$ during the employee's working career while keeping the tax rate at $15 \%$ during retirement and retaining the employer match, the tax deferment becomes more important and the salary penalty increases to $38 \%$ of income. If we increase the marginal tax rate on household income to $35 \%$ during the employee's working career but also increase the tax rate to $25 \%$ during the retirement period, the salary penalty declines to $32 \%$ of income as proportionately more of the tax burden is incurred during retirement period. The salary penalty declines to $32 \%$ of income as proportionately more of the tax burden is incurred during retirement in the case of the participating employee.

In all cases, there is a very significant salary penalty on an employee who is unable to participate in an employer's $401(\mathrm{k})$ plan. Not providing faith-based funds in the plan will impose a very serious burden on the employee because of his religion (equivalent in our case of about $25 \%$ of his income) and is contrary to the stated government purpose of having maximum participation in these plans.

168 See generally supra Part I.A. (describing the qualified plan that provides tax benefits and the existing statutory framework).

169 See generally I.R.C. \& 401(a)(5) (2012) (requiring employers to provide an acceptable investment opportunity for any plan participant to opt in while meeting nondiscrimination requirements).

170 See generally Redman, supra note 68 (explaining that in Sabbatarian accommodation, the focus is on the individual's accommodation). 


\section{Employer Defenses}

If a company's employees can show that their religious needs are not already accommodated within the employer-provided pension plan, then the employer must provide reasonable accommodation unless to do so would create an undue business hardship. ${ }^{171}$ For example, one hardship that Trans World Airline presented in Hardison was a union contract that regulated which workers were assigned to which shifts. ${ }^{172}$ ERISA presents an even greater barrier than a union contract because a contract can be changed with less effort than a statute. ${ }^{173}$

Although employers are not required to follow ERISA when creating private pension plans, ERISA provides such tremendous tax benefits for both employers and employees that the majority of incentives run towards qualifying plans. ${ }^{174}$ Given that the Hardison court found $\$ 150$ to be an undue business hardship, it is safe to assume that any accommodation that might risk disqualifying a pension plan under ERISA is an undue business hardship as well. ${ }^{175}$ Consequently, the only accommodations possible that meet both Title VII and ERISA are: (1) adding an Islamic law compliant fund to the investment options available to all employees; or (2) amending the pension plan in order to allow employees to select their own investments. ${ }^{176}$

Although the cost of adding an additional fund is minimal, so was the financial cost of accommodating Mr. Hardison. ${ }^{177}$ Given the Court's resistance to Title VII's reasonable accommodation rules, either possible accommodation would result in undue business hardship under the Sabbatarian cases. However, until now, the Court has looked at Title VII's reasonable accommodation rules in situations where Congress demands religious accommodation under threat of punishment and without the possibility of reward. ${ }^{178}$ As this Article establishes, the Court's anti-accommodation rules change when

171 See TWA v. Hardison, 432 U.S. 63, 75-77 (1977).

172 See id. at 63 .

173 See $i d$. at 79 (explaining that the parties to the contract can agree to modify the terms, but in this case, "the union was unwilling to entertain a variance"). See generally SINGER \& SINGER, supra note 135, at 778-809 (showing that once the contract ends, the parties are able to negotiate new terms while a statute requires action on the part of the legislature).

174 See I.R.C. 8404.

175 See supra Part I.C.

176 See generally supra Part I (providing general background information regarding Title VII and ERISA).

${ }_{177}$ TWA v. Hardison, 432 U.S. 83, 83-85; id. at 92 n.6 (Marshall, J., dissenting).

178 See supra Part I.C. 
Congress bestows huge financial benefit in exchange for following its statutory requirements. ${ }^{179}$

Qualified pension plans under ERISA bestow tremendous tax benefits on employers and employees alike. ${ }^{180}$ These tax benefits are the equivalent of direct expenditures. In exchange for the federal subsidy that undergirds the private pension system, Congress requires that employers follow certain anti-discrimination provisions in creating their qualified plans. Some of these anti-discrimination provisions are in the ERISA statute, and some are read into ERISA through Title VII.

One anti-discrimination provision read into ERISA through Title VII is religious accommodation in the workplace. The cost of this religious accommodation to the employer although not de minimis is small compared to the enormous benefit to Muslim employees in the private sector who must decline their employer-provided pension plans absent accommodation. The cost is also large to the federal government, which is pouring billions of dollars of tax exemptions into private pension plans in the hope of covering as many workers as possible. When an entire segment of the population is excluded because of a failure to accommodate religious practice in private pension investment options, Congress's intent to cover as many workers as possible under ERISA is thwarted.

\section{ACADEMICS AND RELIGIOUS ACCOMMODATION}

Following the view that the Supreme Court would impose a mandatory obligation to accommodate religion within qualified plan investment options, Part IV posited that the most likely accommodation for Muslim employees is the inclusion of a Shariacompliant fund within the choice of pension options available under the employer-created plan. Under standard ERISA qualifying rules these additional fund options, which exist throughout the Muslim world, would be open to all plan participants. Because the only accommodation option available under ERISA is open to all plan participants, the religious accommodation in pension investments is distinguished from Sabbatarian accommodation under Title VIl in two ways: first, pension plans are supported by government benefit while Sabbatarian accommodation is solely at the employer's (and his employees') expense, and second, the religious accommodation ERISA requires benefits all plan participants equally rather than benefitting

179 See supra Part III.

180 See supra note 24 and accompanying text. 
the religious believer alone. Consequently, this Article posits that Congress through Title VII, the Equal Employment Opportunity Commission through its rulemaking, and the Supreme Court through its decisions in Bob Jones University and Taxation With Representation, all support Congress's right to impose religious accommodation as a requirement for plan qualification under ERISA.

Within the academic community, two other theories of religious accommodation as to a Muslim employee's request for a Shariacompliant investment option in an employer-provided pension fund are part of the discussion. Although religious accommodation has been a part of American law since the colonial period, academics still wonder whether religious accommodation is constitutionally permitted, especially when government attempts to impose an accommodation upon a private citizen engaged in a private transaction. Two prominent schools of thought on the question of the constitutionality of religious accommodation are equal liberty and substantive neutrality.

\section{A. Equal Liberty - An Exemption Based on Equal Regard}

Equal liberty adherents argue that the Constitution's religion clauses are meant to create legal rules that treat the religious and the secular equally. ${ }^{181}$ Using equality as the goal, equal liberty proponents posit that the Constitution does not support religion qua religion exemptions. For example, equal liberty opposes religious exemptions from real property taxes. ${ }^{182}$ Where taxes produce general benefits, equal liberty prefers rules that equally distribute both benefit and cost. ${ }^{183}$ Accordingly, especially for laws of general application, equal liberty adherents are predisposed to oppose any form of tax exemption, particularly an exemption for a wholly religious use. ${ }^{184}$

In the case of private-employer-sponsored pension plans, equal liberty proponents might argue their default position of no accommodation because expanding pension plan investment choices in order to include Islamic-approved funds accommodates religion qua

181 Christopher L. Eisgruber \& LaWrence G. Sager, Religious Freedom and the CONSTITUTION 1-33, 87 (2007) ("Equal Liberty begins with the idea that religious liberty, above all, requires that persons not be treated unequally on account of the spiritual foundations of their deep commitments.").

182 See, e.g., Walz v. Tax Comm'n of N.Y.C., 397 U.S. 664, 700-16 (1970) (Douglas, J., dissenting) (arguing that any tax exemption to religion qua religion is unconstitutional as an Establishment).

183 EISGRUBER \& SAGER, supra note 181 , at 104.

184 Id. at 87-88. 
religion. Generally, if equal liberty allows accommodation for a religious practice, it is when that practice is included within a larger secular group that naturally encompasses religion. ${ }^{185}$ In order to satisfy this equal liberty standard, an equivalent secular practice must be identified and accommodated. ${ }^{186}$

One type of accommodation that encompasses Muslim concerns about investing - but is wider than mere religious accommodation is an accommodation for social investing. Although framing a request for Sharia-compliant investment options as part of a larger request for access to social justice investing meets equal liberty concerns by providing accommodation based on something other (and larger than) religion, there is no basis for demanding access to social investing options as part of a qualified plan for two reasons. First, under Title VII, an employee must show a bona fide religious belief. ${ }^{187}$ An equivalent secular practice has no protection. ${ }^{188} \mathrm{Next}$, a demand for social investing should not survive ERISA's prudent investor rules. ${ }^{189}$

Under section 91 of the American Law Institute's Restatement Third of the Law of Trusts, the trust's creator can restrict the trustee's ability to invest. ${ }^{190}$ Thus, under the common law of trusts, a creator can compel a trustee to invest in accordance with restrictions in the trust documents. For example, the creator could require that trust funds are only placed in socially responsible investments. ${ }^{191}$

185 Id. at 203.
186 Id.

187 See 29 C.F.R. \$ 1605.1 (2012); see also EQUAL EMPLOYMENT OPPORTUNITY COMM'N, supra note 8 , at 7-8.

188 See 29 C.F.R. \$ 1605.1

189 See Ian D. Lanoff, The Social Investment of Private Pension Plan Assets: May It Be Done Lawfully Under ERISA?, 31 LAB. L.J. 387, 388 (1980) ("ERISA is a worker protection law with an already existing social purpose: to protect Employee Retirement Income Security" and that the Department of Labor has exclusive authority to interpret and enforce ERISA fiduciary standards); see also ERISA Enforcement, U.S. DEP'T OF LABOR, http:/www.dol.gov/ebsa/erisa_enforcement.html (last visited Sept. 14, 2012).

190 See Restatement (Third) of Trusts: Investment Provisions of Statute or TRUST $\S \S 91(a), 79$ (2007) (stating that the trustee in investing the funds of the trust has "a duty to conform to any applicable statutory provisions governing investment by trustees"). The applicable statutory provisions in this instance would be ERISA $\S \S$ 403-404 (codified at 29 C.F.R. \$ 2509.94-1).

191 See generally John Langbein \& Richard A. Posner, Social Investing and the Law of Trusts, $79 \mathrm{MICH}$. L. REV. 72 (1980) (defining social investing to mean excluding the securities of certain otherwise attractive companies from an investor's portfolio because the companies are judged to be socially irresponsible, and including the securities of certain otherwise unattractive companies because they are judged to be behaving in a socially laudable way). 
Although the case law and regulations are scant on the subject, the weight of opinion is that ERISA's prudent investor standard does not allow social investing to the extent permitted by section 91 of the Restatement of Trusts. ${ }^{192}$ Rather, because the sole purpose of the qualified plan is to fund participants' retirement accounts, the prudent investor standard does not allow the trustee to invest in order to reap secondary benefits from social investing. ${ }^{193}$ Ironically, to the extent that courts have allowed social investing to inform pension investment decisions, those social justice choices are made to support the employer's interests in social investing, as against the plan beneficiaries' interests in strong financial returns. ${ }^{194}$

For example, in Lipton v. Consumers Union of United States, Inc., the District Court allowed the employer to restrict its pension fund investments to "socially responsible equity mutual funds" over the plan participants' objections. ${ }^{195}$ The employer, the publisher of Consumer Reports Magazine, argued that it was compelled to consider social themes when investing because of its corporate reputation. ${ }^{196}$ The employees' complaint that Consumer Reports' social justice investments undermined the plan participants' need for the best economic returns was dismissed on summary judgment for failure to show "theft, misappropriation, or diversion of monies." 197 Another example of an employer using pension funds for social investing is Withers v. Teachers' Retirement System of City of New York, in which New York City was allowed to invest pension funds in risky bonds that were used to finance middle class housing in the city's outer boroughs. ${ }^{198}$

Some might argue that political beliefs require the same level of regard as religious beliefs. That seems to be the lesson of Welsh and Seeger. ${ }^{199}$ Yet, there is no non-religious accommodation rule under Title VII. Consequently, equal liberty proponents have two

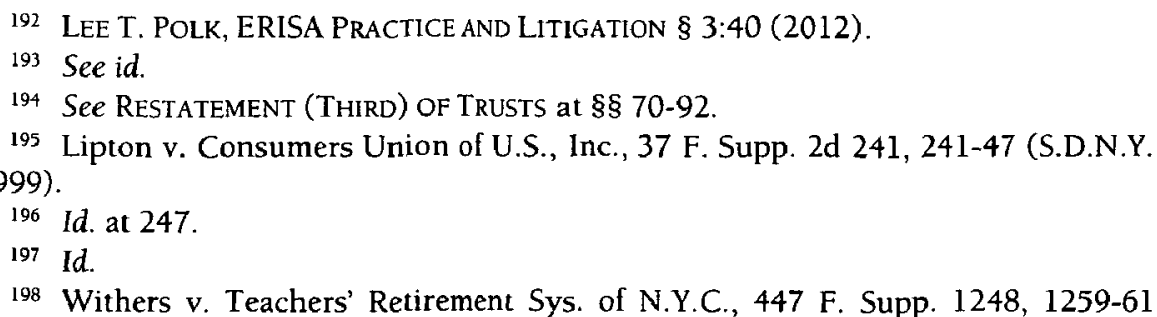
(S.D.N.Y. 1978) (finding that the trustees, after careful deliberation, believed that "the alternative to purchasing the "highly speculative" city bonds would be the bankruptcy of their own retirement fund" and made a prudent decision that fulfilled their fiduciary obligations), affd, 595 F.2d 1210 (2d Cir. 1979).

199 See discussion supra Part IV.A. 
independent reasons for rejecting a religious accommodation under Title VII for pension investments: (1) a general antipathy to religion qua religion accommodation; and (2) the lack of any attempt under Title VII to provide for comparable sincerely held secular beliefs. ${ }^{200}$

Nevertheless, even with laws of general application, equal liberty adherents sometimes accept a religious exemption where the lack of accommodation is due to a lack of equal regard for the religious practice. Proponents of equal liberty test equal regard by asking if a mainstream religion would receive the exemption under similar circumstances. For example, in Lyng v. Northwest Indian Cemetery Protective Association, the federal government planned a road across a piece of sacred Indian land. ${ }^{201}$ The Supreme Court allowed the road to go forward. However, equal regard adherents criticized the Court's decision, speculating that the Justices would not allow a similar road across land that was sacred to mainstream Protestants. ${ }^{202}$

Under the equal regard test, we ask ourselves whether a statute would tolerate a private pension plan that contained no investments a mainstream Christian employee could morally include in a retirement plan. A plan that was closed to mainstream Christian employees would most likely fail to qualify under ERISA by being overly weighted toward the highly compensated. ${ }^{203}$ However, it is hard to believe that ERISA and Title VII would allow a pension plan that was completely unacceptable to mainstream Christians even if the workforce contained very few Christians. ERISA is meant to include workers within its protections, not allow structures that keep employees out of the private pension and welfare system. ${ }^{204}$ Equal regard is meant to force us to ask whether we would carve an exception if we understood the religious practice that seeks the accommodation.

200 See supra Part IV.A. See generally Christopher L. Eisgruber and Lawrence G. Sager, The Vulnerability of Conscience: The Constitutional Basis for Protecting Religious Conduct, 61 U. CHI. L. Rev. 1245, $1245-1315$ (1994) (examining exemptions from generally applicable law).

201 Lyng v. NW. Indian Cemetery Protective Ass'n, 485 U.S. 439, 439-40 (1988) (determining that the Free Exercise Clause does not prohibit the Government from permitting timber harvesting in the Chimney Rock area or constructing the proposed road).

202 EISGRUBER \& SAGER, supra note 181, at 91-92, 242-244.

203 See supra text accompanying note 41. When misused, ERISA contains tax incentives for the highly compensated if the qualified plan can keep out lower income participants. ERISA blocks these efforts by forcing plans to have widespread eligibility. By restricting plan investments so that Christians could not invest, highly compensated non-Christians could reap all the tax benefits of a plan for themselves.

204 See discussion supra Part I. 
Given the extremely small cost to the employer of adding a fund, the huge cost to employees (up to ten years salary due to lost tax benefits) in keeping Muslims out of the plan, and the tremendous government subsidy represented by ERISA, it is likely that equal liberty proponents would support a religious accommodation in pension investment planning. The facts meet the requirements for accommodation as set out by equal liberty proponents: the accommodation would happen as a matter of course if the majority of the population held the same belief, the harm is great on one side, and the accommodation is not costly on the other side. Thus, equal liberty proponents would allow the accommodation to the same extent as the Supreme Court in Bob Jones University and Taxation with Representation.

\section{B. Substantive Neutrality - Discretionary Accommodation and Occasional Mandatory Accommodation}

Substantive neutrality scholars point out that religious accommodation is routine in American law. ${ }^{205}$ Thus, the question is not whether the Constitution allows religious accommodation, but rather what type of religious accommodation best serves the religion clauses. Substantive neutrality approves religious accommodations that prevent government from either encouraging or discouraging religion.

For example, substantive neutrality approves of Sherbert $v$. Verner, where the Supreme Court refused to allow South Carolina to force Ms. Sherbert to choose between her religion and her unemployment insurance. ${ }^{206}$ The Court's decision is substantively neutral because the accommodation ensures that Ms. Sherbert was neither encouraged nor

205 See Michael W. McConnell, The Problem of Singling out Religion, 50 DEPAUL L. REv. 1, 3, 5 (2000). In considering religious exemptions, Michael W. McConnell explained:

Religion-specific exemptions are relatively common in our law, even after Smith. As a matter of constitutional rights, Smith left intact the requirement of strict scrutiny for laws burdening religious exercise in two contexts: where the burden is imposed on a case-by-case basis rather than pursuant to a generally applicable law, and where the burden to religious exercise is combined with a burden to some other constitutional right.

Id. at 3 .

${ }^{206}$ Sherbert v. Verner, 374 U.S. 398, 401-02 (1963). Adell Sherbert, a Seventh-day Adventist, quit her job rather than work on Saturday, her Sabbath. Id. at 399. To be eligible for benefits, the court required one to have "good cause" for turning down work. Id. at 400 . The state took the position that Ms. Sherbert lacked "good cause," as she would have had work had she been willing to work on Saturdays, her Sabbath. Id. 
discouraged in her religious beliefs in that she received unemployment insurance coverage in either case. ${ }^{207}$

In the pension situation, the lack of Sharia-compliant investment options forces the Muslim employee to choose between his religion and his retirement. If the Congress, rather than a private employer, forced the employee to choose between retirement savings and religion, then the holding in the Sherbert case would force Congress to make an accommodation under Sherbert, which still applies to Congress by virtue of the Religious Freedom Restoration Act. ${ }^{208}$ In contrast, if the State rather than the federal government forced the employee to choose between retirement savings and religion, the Employment Division v. Smith decision would not force the State to provide a religious accommodation, but neither would the Court condemn the State for making an accommodation. ${ }^{209}$

207 Id. at 404 (finding that "[i]f the purpose or effect of a law is to impede the observance of one or all religions or is to discriminate invidiously between religions, that law is constitutionally invalid even though the burden may be characterized as being only indirect").

${ }^{208}$ The Court's disavowal of strict scrutiny and compelling state interest as tools for judging when to enforce religious accommodation against a state's failure to provide the accommodation itself in Employment Division of Oregon v. Smith, 494 U.S. 872 (1990), moved Congress to pass the Religious Freedom Restoration Act. See Religious Freedom Restoration Act of 1993, Pub. L. No. 103-141, 107 Stat. 1488 (1993) (codified at 42 U.S.C. \& 2000bb). In the Religious Freedom Restoration Act, Congress echoed the Court's observation in Sherbert that generally neutral laws may burden free exercise. See Sherbert, 374 U.S. at 403-05. In order to correct the effect of these generally neutral but burdensome laws, the Religious Freedom Restoration Act directed the Court to abandon Smith's approach (allowing general laws that are generally applied to burden religion) in favor of Sherbert's and Wisconsin v. Yoder's compelling state interest test (forcing occasional mandatory accommodation on the states). See 42 U.S.C. \& 2000 b (2012); Wisoncomsin v. Yoder, 406 U.S. 215, 221 (1972); Sherbert, 374 U.S. at 398. In other words, Congress used the Religious Freedom Restoration Act to direct the Court back to the Court's prior, pro mandatory accommodation standard that held states to strict scrutiny and compelling state interest. In the Religious Freedom Restoration Act Congress repudiated Smith, which allows states to accommodate religion or not at the will of each state's legislature.

209 Smith, 494 U.S. at 890. In Smith, the Court dismantled Sherbert and allowed the Oregon to deny unemployment benefits to workers fired for engaging in the religious use of peyote. Smith, 494 U.S. at 890 . Rather than applying strict scrutiny and requiring that Oregon show a compelling state interest in denying the unemployment insurance claims, as the Court had previously done when overturning state unemployment insurance laws in Sherbert, 374 U.S. at 404, Thomas v. Review Board of Indiana, 450 U.S. 707 (1981), Hobbie v. Unemployment Appeals Commission of Florida, 480 U.S. 136 (1987), and Frazee v. Illinois Department of Employment Security, 489 U.S. 829 (1989). The Smith court found no prohibited burden on free exercise when Oregon did not exempt religious use of peyote from a general criminal statute that was evenly applied. Smith, 494 U.S. at 878-79. If Oregon's unemployment insurance 
In Title VII, Congress attempted to make an accommodation through the private employer and backed up that accommodation obligation with substantial government subsidy. In keeping with Congress's rules under ERISA, the accommodation must be available to all plan participants. Supporters of substantive neutrality would applaud a mandatory religious accommodation in pension plan investment options because the accommodation is neutral as between the religious and the non-religious, both of whom are allowed to invest in the same broad range of funds.

\section{CONCLUSION}

This Article asks whether Muslims whose religious beliefs prevent investment in their employers' private pension plans have a right to religious accommodation. This question is a real issue for a growing part of the population whose spiritual lives are governed by rules that prohibit the giving or taking of interest. ${ }^{210}$ As one might expect, the investments available through most American pension plans involve some aspect of interest, making those investments unsuitable retirement vehicles for devout Muslims. Consequently, in order to secure their retirement income, Muslims are faced with either violating their religious beliefs, waiting for the American investment market to meet their religious needs, relying on their employer's goodwill, or religious accommodation through court or statute.

Religious accommodation in the workplace is governed by Title VII. The statute is directive and punitive. There are potential money damages if an employer does not comply with Title VII's religious accommodation requirement but no benefit (monetary or otherwise) in exchange for compliance.

statute then denied coverage to these believers because they engaged in illegal acts which counted as employee misconduct, then the Court could not force the state to create a religious exemption to its generally applicable laws.

The government's ability to enforce generally applicable prohibitions of socially harmful conduct, like its ability to carry out other aspects of public policy, cannot depend on measuring the effects of a governmental action on a religious objector's spiritual development. To make an individual's obligation to obey such a law contingent upon the law's coincidence with his religious beliefs, except where the State's interest is 'compelling'-permitting him, by virtue of his beliefs, 'to become a law unto himself,' contradicts both constitutional tradition and common sense.

Id. at 885 (citations omitted).

210 See supra note 2 and accompanying text. 
The two Supreme Court decisions that look at religious accommodation under Title VII concern private employers asked to rearrange employee work schedules to accommodate Sabbatarians. ${ }^{211}$ Where the employer faced a potential penalty for failure to provide religious accommodation but no benefit for compliance with the statute's requirements, the Court treated the Title VII accommodation obligation as an establishment of religion and as a burden on the employer's and non-believer employees' Free Exercise rights. Accordingly, the Court diminished Congress's religious accommodation rule under Title VII to the point that no motivated employer need ever accommodate an employee's religious practice.

Not all religious accommodations occur in the same context. As opposed to religious accommodation under Title VII, the Court generally gives Congress great deference when the legislature bestows tax benefits in exchange for taxpayers eschewing even constitutionally protected activities. ${ }^{212}$ Private pension plans are founded on tremendous tax benefits bestowed on retirement accounts by ERISA. These benefits invoke the Court's deference to Congress exhibited in the Court's tax decisions rather than the hostility to forced religious accommodation reflected in its Title VII decisions.

Using retirement savings as a model, this Article challenges the notion that a motivated employer can always avoid religious accommodation. Instead the Article argues that, when government confers tax benefits, as it does to private pensions, then Title VII's religious accommodation provisions - as well as its prohibitions against other types of discrimination - are greatly enhanced, because Congress may impose obligations in return for tax benefits without violating constitutional prohibitions. The intersection of tax policy and religious accommodation allows for greater consideration of Supreme Court decisions that reflect a more deferential attitude towards Congress and towards accommodation than the Court generally demonstrates under Title VII.

211 See generally TWA v. Hardison, 432 U.S. 63 (1977) (evaluating accommodation of an employee whose religious beliefs prohibited him from working on Saturdays); Ansonia Bd. of Educ. v. Philbrook, 479 U.S. 60 (1986) (evaluating accommodation of a member of the Worldwide Church of God).

212 See discussion supra Part III. 
